\title{
HYDROLOGICAL STUDY AND ANALYSIS FOR PROPOSED SARTIK DAM PART 2: RESERVOIR CHARACTERISTICS, SIMULATION MODEL, AND FLOOD ROUTING CALCULATIONS
}

\author{
Basil Younus Mustafa \\ Dept. of Civil Engineering, Erbil Technical Engineering College Erbil , Erbil Polytechnic University, Kurdistan Region-Iraq
}

\begin{abstract}
This research is the part 2 of hydrological study and analysis for proposed Sartik dam which located on the Lesser Zab River, the second largest tributary of Tigris River at $18 \mathrm{~km}$ northeast of Altun Kopri town, within Erbil governorate of Iraqi Kurdistan Region. In this part water demand from the dam is calculated, the dam power generating facility with an installed capacity amounting to $156 \mathrm{MW}$ with a maximum discharge of $300 \mathrm{~m}^{3} / \mathrm{sec}$. The characteristics of the dam reservoir were calculated, from reservoir sedimentation calculation the dead storage level and capacity was determined and was equal to (309 m.a.s.l., and $104,304,031 \mathrm{~m}^{3}$ ) respectively. The monthly and annual water losses due to evaporation were calculated from daily recorded evaporation using an equation based on area, volume and elevation curve, and the annual losses were equal to $\left(51,132.366 \mathrm{~m}^{3}\right)$, also the normal reservoir water level (NWL) was fixed at 325 m.a.s.l. which gives live storage capacity equal to $(384,846,885)$, and flooded area equal to $\left(34.184 \mathrm{~km}^{2}\right)$. The simulation model of the dam reservoir, prepared from the calculation of water inflow into the reservoir and water demand including evaporation losses. The inflow was taken for different types of water years, dry (deficit) years (1984, and 1999), average water years (1981, and 1995) inflow, and maximum (flood) water years (1969 and 1988) inflow. From the curves, it is clear that the reservoir starts full at month April and ends full at month March during one year taking into account that the maximum water storage in the reservoir is $(489,150,916) \mathrm{m}^{3}$ and minimum storage is $(104,304,031) \mathrm{m}^{3}$. The flood routing study was done using the (PMF, 1000, 100, 50, and 25) years return periods inflow hydrographs, and stage and volume curve by fixing the crest level of ogee spillway will at 320 m.a.s.l., choosing the number of gated spans equal to 7 , the length of each span equal to $12 \mathrm{~m}$, and the initial water level of the reservoir was 325 m.a.s.l. The results of this routing will be used to determine the design parameters of the spillway and to determine the actual need of the emergency spillway.
\end{abstract}

KEYWORDS: Reservoir Characteristics, Water Demand, Sedimentation, Evaporation Losses, Simulation Model, Flood Routing

\section{INTRODUCTION:}

$\mathbf{K}^{2}$ urdistan region of Iraq is frequently subjected to a severe drought, which causes shortages for the region population, as the available water resources to not satisfy water demands for domestic, livestock consumption, agriculture, tourism and environment requirements. Therefore, the water resources management becomes one of the most important issues at the same time intensive rain causes runoff at times that take substantial amounts away from where it falls and after lost. Water harvesting is a useful practice to capture runoff and utilize in situ for various uses especially supplemental irrigation during drought spells [3].

In order to satisfy water management of the area, investigations and studies started for water harvesting through the construction of small and medium dams everywhere feasible, that aims at collection of excess water and in conservation of the eroded soil, in addition to ground water recharge. Many locations in Erbil Governorate were proposed for conducting feasibility studies and design of small and medium dams in order to reclaim water resources of Erbil Governorate. Sartik location in Altun Kopri District is one of the areas was selected for the above object in order to reclaiming water resources of the area.

\section{2- CALCULATION OF WATER DEMAND:}

The possibility of meeting the expected future demand with its seasonal variations will be greatly dependent on the possibility of arranging sufficient storage capacity in the river Tigris and its tributaries.

The amounts of precipitation in the dam site are between 300-400 mm/year. Most precipitation occurs from October to March. Such precipitation depths are not sufficient for all daily requirements (especially for irrigation). Thus, agricultural 
development in these areas depends on the amount of surface water available for irrigation. The existing Dokan reservoir allows for a fairly high degree of regulation of the water flow in the Lesser Zab. The yearly average regulated discharge at Dokan is $208 \mathrm{~m}^{3} / \mathrm{sec}$ of which a firm irrigation discharge of about $110 \mathrm{~m}^{3} / \mathrm{sec}$ can be obtained at present. The planned Sartik reservoir may increase the firm irrigation discharge up to $125 \mathrm{~m}^{3} / \mathrm{sec}$.

The power generation is considered as a byproduct of irrigation. The power output for the Sartik dam is computed on the basis of monthly flows, total irrigation requirements and average monthly heads.

The firm power from the Sartik dam is the minimum power output. That is, the power that could be produced with the flow covering the monthly minimum (irrigation and non-irrigation water demands desired below Sartik dam) that passes through the turbines at the minimum head.

Sartik dam may have a power generating facility with an installed capacity amounting to 156 MW with a maximum discharge of 300 $\mathrm{m}^{3} / \mathrm{sec}$. This is governed by the seasonal variations of river Lesser $\mathrm{Zab}$ flow, power generation in Dokan dam and irrigation demands downstream.

For better flexibility of operation, 3units are found the optimum number to be installed, each having a capacity of $52 \mathrm{MW}$ and a maximum discharge of $\left(100 \mathrm{~m}^{3} / \mathrm{sec}\right)$. The total monthly water requirements for irrigation and other (domestic, industrial supplies, power product and others) are given in Table (2-1).

Table( 2.1):- Water requirement for downstream users - monthly distribution

\begin{tabular}{ccc}
\hline Month & \multicolumn{2}{c}{ Total Water Requirements } \\
\cline { 2 - 3 } & $\mathrm{m}^{3} / \mathrm{sec}$ & $\left(\mathrm{m}^{3} \times 1000\right)$ \\
\hline January & 102 & 273,196 \\
\hline February & 108 & 261,273 \\
\hline March & 120 & 321,408 \\
\hline April & 141 & 365,472 \\
\hline May & 151 & 404,438 \\
\hline June & 300 & 803,520 \\
\hline July & 300 & 803,520 \\
\hline August & 300 & 803,520 \\
\hline September & 300 & 803,520 \\
\hline October & 151 & 404,438 \\
\hline November & 104 & 269,568 \\
\hline December & 88 & 235,699 \\
\hline Total & 2165 & $5,749,572$ \\
\hline Mean & 180 & 479,131 \\
\hline
\end{tabular}

\section{3- SARTIK DAM RESERVOIR} CHARACTERISTICS

\section{3-1 Reservoir Area - Volume Capacity Curves:}

Water management calculations require reservoir characteristics in the form of curves relating volumes, levels, and water surface areas. These relationships are based on topographic descriptions of the reservoir expressed as a relationship between its water surface area and level. The surface areas of the reservoir at various elevations for a contour interval of $(1 \mathrm{~m})$ up to an elevation of (340 m.a.s.1.) were obtained by the surveying team. The volumes of the reservoir between the contours were obtained by the following equation (1) [4], and then the calculated volumes for each contour were accumulated as shown in the table (3-1).

$$
\mathbf{V}=\left(\frac{\mathbf{H}}{3}\right) *\left(\mathbf{A}_{\mathbf{1}}+\mathbf{A}_{\mathbf{2}}+\sqrt{\mathbf{A}_{\mathbf{1}} * \mathbf{A}_{\mathbf{2}}}\right)
$$

Where: $\mathrm{H}$ is contour interval $(\mathrm{m}), \mathrm{A}_{1}=$ Area of top contour $\left(\mathrm{m}^{2}\right)$, and $\mathrm{A}_{2}=$ Area of bottom contour $\left(\mathrm{m}^{2}\right)$.

Figure (1) shows Elevation, Area-Storage curves, while figure (2) shows Area-Storage curve, From the below data a non-linear regression analysis has been made and a suitable equation, is formulated to fit the Area-Storage curve as shown in the figure (2). 
Table (3-1): Sartik Dam Elevation, Area, and storage capacity calculation

\begin{tabular}{|c|c|c|c|c|}
\hline Elevation $(\mathrm{m})$ & Area $(A)\left(m^{2}\right)$ & $\operatorname{SQR}\left(A_{1}+A_{2}\right)$ & Volume $\left(\mathrm{m}^{3}\right)$ & Accum. Volume $\left(\mathrm{m}^{3}\right)$ \\
\hline 290 & $o$ & 0 & 0 & 0 \\
\hline 291 & $1,405,413$ & 0 & 468,471 & 468,471 \\
\hline 292 & $1,405,413$ & $1,405,413$ & $1,405,413$ & $1,873,884$ \\
\hline 293 & $1,405,413$ & $1,405,413$ & $1,405,413$ & $3,279,297$ \\
\hline 294 & $1,405,413$ & $1,405,413$ & $1,405,413$ & $4,684,710$ \\
\hline 295 & $1,405,413$ & $1,405,413$ & $1,405,413$ & $6,090,123$ \\
\hline 296 & $2,368,285$ & $1,824,395$ & $1,866,031$ & $7,956,154$ \\
\hline 297 & $3,018,258$ & $2,673,592$ & $2,686,712$ & $10,642,866$ \\
\hline 298 & $3,518,602$ & $3,258,842$ & $3,265,234$ & $13,908,100$ \\
\hline 299 & $3,952,291$ & $3,729,147$ & $3,733,347$ & $17,641,446$ \\
\hline 300 & $5,014,556$ & $4,451,852$ & $4,472,900$ & $22,114,346$ \\
\hline 301 & $6,184,477$ & $5,568,878$ & $5,589,304$ & $27,703,650$ \\
\hline 302 & $7,161,044$ & $6,654,871$ & $6,666,797$ & $34,370,447$ \\
\hline 303 & $8,200,803$ & $7,663,309$ & $7,675,052$ & $42,045,499$ \\
\hline 304 & $8,693,512$ & $8,443,564$ & $8,445,960$ & $50,491,459$ \\
\hline 305 & $9,126,816$ & $8,907,530$ & $8,909,286$ & $59,400,745$ \\
\hline 306 & $10,334,444$ & $9,711,878$ & $9,724,379$ & $69,125,124$ \\
\hline 307 & $10,999,971$ & $10,662,016$ & $10,665,477$ & $79,790,601$ \\
\hline 308 & $12,246,849$ & $11,606,678$ & $11,617,833$ & $91,408,434$ \\
\hline 309 & $13,555,412$ & $12,884,529$ & $12,895,597$ & $104,304,031$ \\
\hline 310 & $14,869,013$ & $14,197,028$ & $14,207,151$ & $118,511,182$ \\
\hline 311 & $16,239,905$ & $15,539,349$ & $15,549,422$ & $134,060,604$ \\
\hline 312 & $17,809,080$ & $17,006,404$ & $17,018,463$ & $151,079,067$ \\
\hline 313 & $19,117,202$ & $18,451,552$ & $18,459,278$ & $169,538,345$ \\
\hline 314 & $20,517,943$ & $19,805,193$ & $19,813,446$ & $189,351,791$ \\
\hline 315 & $21,317,234$ & $20,913,770$ & $20,916,316$ & $210,268,107$ \\
\hline 316 & $22,853,687$ & $22,072,095$ & $22,081,005$ & $232,349,112$ \\
\hline 317 & $23,771,575$ & $23,308,113$ & $23,311,125$ & $255,660,237$ \\
\hline 318 & $25,127,898$ & $24,440,330$ & $24,446,601$ & $280,106,838$ \\
\hline 319 & $26,421,725$ & $25,766,692$ & $25,772,105$ & $305,878,943$ \\
\hline 320 & $26,958,134$ & $26,688,582$ & $26,689,480$ & $332,568,423$ \\
\hline 321 & $29,262,350$ & $28,086,622$ & $28,102,369$ & $360,670,792$ \\
\hline 322 & $30,669,667$ & $29,957,746$ & $29,963,254$ & $390,634,046$ \\
\hline 323 & $32,265,032$ & $31,457,237$ & $31,463,979$ & $422,098,025$ \\
\hline 324 & $33,831,241$ & $33,038,857$ & $33,045,043$ & $455,143,068$ \\
\hline 325 & $34,184,760$ & $34,007,541$ & $34,007,847$ & $489,150,916$ \\
\hline 326 & $36,331,363$ & $35,241,721$ & $35,252,615$ & $524,403,531$ \\
\hline 327 & $38,010,234$ & $37,161,319$ & $37,167,639$ & $561,571,169$ \\
\hline 328 & $39,603,202$ & $38,798,543$ & $38,803,993$ & $600,375,162$ \\
\hline 329 & $41,103,188$ & $40,346,225$ & $40,350,872$ & $640,726,034$ \\
\hline 330 & $41,389,747$ & $41,246,219$ & $41,246,385$ & $681,972,418$ \\
\hline 331 & $44,162,862$ & $42,753,827$ & $42,768,812$ & $724,741,230$ \\
\hline 332 & $45,482,562$ & $44,817,855$ & $44,821,093$ & $769,562,323$ \\
\hline 333 & $46,858,960$ & $46,165,632$ & $46,169,051$ & $815,731,374$ \\
\hline 334 & $48,365,022$ & $47,606,036$ & $47,610,006$ & $863,341,380$ \\
\hline 335 & $48,599,902$ & $48,482,320$ & $48,482,415$ & $911,823,795$ \\
\hline 336 & $51,876,662$ & $50,211,559$ & $50,229,374$ & $962,053,169$ \\
\hline 337 & $54,111,578$ & $52,982,337$ & $52,990,192$ & $1,015,043,362$ \\
\hline 338 & $56,642,681$ & $55,362,667$ & $55,372,309$ & $1,070,415,670$ \\
\hline 339 & $57,420,470$ & $57,030,250$ & $57,031,134$ & $1,127,446,804$ \\
\hline 340 & $58,226,771$ & $57,822,215$ & $57,823,152$ & $1,185,269,956$ \\
\hline
\end{tabular}

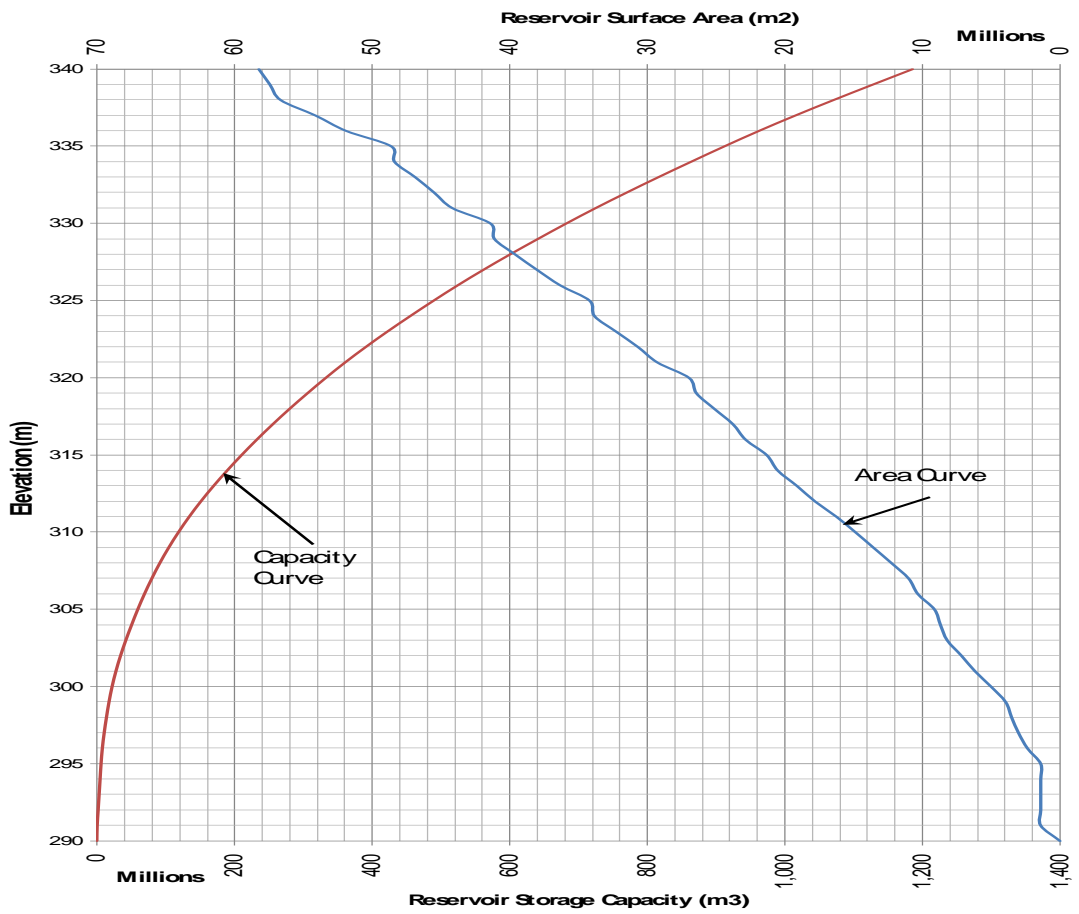




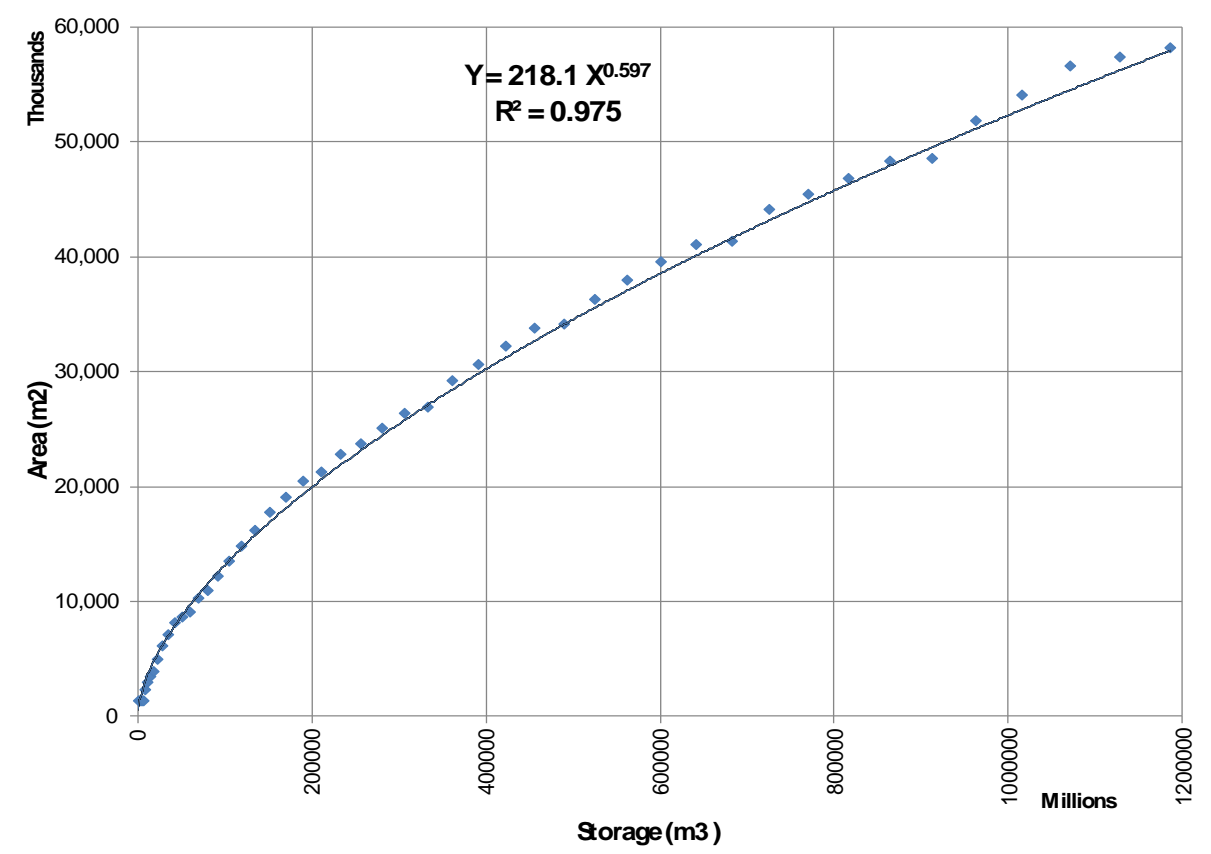

Fig. (2): Area and Storage capacity curve for Sartik Dam

\section{3-2 Reservoir Sedimentation:}

The material transported in a river can generally be divided into suspended load, carried in the suspension by the water, and bed load moved along the bottom by the water. The maximum sediment transport takes place during periods of high flows, often during a few flood days each year. Measurements of suspended load are regularly undertaken, in the Lesser-Zab River at Altun Kopri/Goma Zerdala gauging station. Observation of suspended load concentration and corresponding discharge values for the period 1971- 1980 are given in the table (3-2) [13]. These values refer to regulated conditions.

The regression equation between suspended sediment load and daily average discharge is: -

$$
\text { SSL }=0.000376 * \mathbf{q}^{1.366}
$$

Where, SSL $=$ Suspended sediment load in million $\mathrm{kg} / \mathrm{day}$, and $\mathrm{q}=$ Daily average discharge in $\mathrm{m}^{3} / \mathrm{sec}$ at Goma Zerdala gauging station.

With the use of the above equation and the duration curve for the dam site, the mean annual suspended sediment load had been calculated (by SWECO, 1982) [13] to be about 1.1 million tons. No bed - load measurements are available for the Lesser-Zab River. The amount of the bed - load is difficult to estimate, but for rivers with catchment displaying similar erosion proneness, it is of the order of $(20-30) \%$ of the suspended load.
Assume a bed load concentration of $30 \%$, the total sediment load is 1.45 million ton / year. Based on sediments density of $1.2 \mathrm{ton} / \mathrm{m}^{3}$, the total volume of deposited sediments is 1.2 Million $\mathrm{m}^{3} /$ year.

The deposition of sediment gradually reduces the available storage capacity of the reservoir. When the useful capacity is reduced that is not able to serve the required purpose, the useful life of the reservoir is considered to be over. The sedimentation of a reservoir is measured in terms of trap efficiency (Te), is defined as the percent of the inflowing sediment which is retained in a reservoir and it's a function of the ratio of the reservoir capacity to average annual water inflow(equation 3) [4].

$$
\mathbf{T}_{\mathrm{e}}=\mathbf{f}\left(\frac{\text { Resesvoir Capacity }}{\text { Average annual inflow }}\right)
$$

The probable useful life for the proposed dam reservoir is shown in the table (3-3) below of an initial capacity of $681,972,418 \mathrm{~m}^{3}$, the average annual inflow of $7,379,424,000 \mathrm{~m}^{3}$, and the average annual sediment inflow is $1,200,000 \mathrm{~m}^{3}$. Assuming that the useful life of the reservoir will terminate when $80 \%$ of its initial capacity is filled with sediment. From above one can show the trap volume of sediment for 100 year = $104,304,031 \mathrm{~m}^{3}$, this volume will be considered as reservoir dead storage. 
Table (3-2) :-Records of suspended sediment concentration for period (1971-1979)

\begin{tabular}{|c|c|c|c|c|c|c|c|}
\hline Date & $\begin{array}{c}\text { Average } \\
\text { daily } \\
\text { discharge } \\
\left(\mathrm{m}^{3} / \mathrm{sec}\right)\end{array}$ & $\begin{array}{c}\text { Average } \\
\text { sediment } \\
\text { concentration } \\
(\mathrm{ppm})\end{array}$ & $\begin{array}{l}\text { Sediment } \\
\text { load } \\
\left(10^{6} \mathrm{~kg} / \mathrm{d}\right)\end{array}$ & Date & $\begin{array}{l}\text { Average } \\
\text { daily } \\
\text { discharge } \\
\left(\mathrm{m}^{3} / \mathrm{sec}\right)\end{array}$ & $\begin{array}{c}\text { Average } \\
\text { sediment } \\
\text { concentration } \\
(\mathrm{ppm})\end{array}$ & $\begin{array}{c}\text { Sediment } \\
\text { load } \\
\left(10^{6} \mathrm{~kg} / \mathrm{d}\right)\end{array}$ \\
\hline $19 / 5 / 1971$ & 64 & 286 & 1.58 & $1 / 7 / 1974$ & 87 & 62 & 0.47 \\
\hline $5 / 1 / 1972$ & 107 & 67 & 0.62 & $27 / 7 / 1974$ & 288 & 123 & 3.06 \\
\hline $3 / 2 / 1972$ & 119 & 210 & 2.16 & $1 / 9 / 1975$ & 294 & 80 & 2.03 \\
\hline $14 / 2 / 1972$ & 197 & 302 & 5.14 & $5 / 11 / 1975$ & 259 & 33 & 0.74 \\
\hline $8 / 3 / 1972$ & 287 & 212 & 5.26 & $31.12 / 1975$ & 233 & 1069 & 21.52 \\
\hline $8 / 4 / 1972$ & 273 & 210 & 4.95 & $4 / 2 / 1976$ & 101 & 137 & 1.20 \\
\hline $5 / 9 / 1972$ & 284 & 243 & 5.96 & $23 / 9 / 1978$ & 433 & 480 & 17.96 \\
\hline $3 / 10 / 1972$ & 314 & 221 & 6.00 & $30 / 11 / 1978$ & 326 & 287 & 8.08 \\
\hline $9 / 12 / 1972$ & 215 & 116 & 2.15 & $27 / 12 / 1978$ & 354 & 453 & 13.85 \\
\hline $11 / 1 / 1973$ & 303 & 136 & 3.56 & 4/1/ 1979 & 286 & 357 & 8.82 \\
\hline $18 / 2 / 1973$ & 259 & 362 & 8.10 & $13 / 1 / 1979$ & 293 & 337 & 8.53 \\
\hline $9 / 3 / 1973$ & 260 & 341 & 7.66 & $20 / 1 / 1979$ & 508 & 3345 & 146.82 \\
\hline $19 / 4 / 1973$ & 113 & 802 & 7.83 & $27 / 2 / 1979$ & 112 & 1233 & 11.93 \\
\hline $12 / 6 / 1973$ & 72 & 97 & 0.60 & $16 / 4 / 1979$ & 28 & 225 & 0.54 \\
\hline $13 / 7 / 1973$ & 225 & 535 & 10.40 & $21 / 5 / 1979$ & 54 & 73 & 0.34 \\
\hline $13 / 8 / 1973$ & 363 & 175 & 2.46 & $28 / 8 / 1979$ & 258 & 33 & 0.74 \\
\hline $11 / 9 / 1973$ & 269 & 175 & 4.07 & $2 / 10 / 1979$ & 345 & 103 & 3.07 \\
\hline $4 / 10 / 1973$ & 290 & 164 & 4.11 & $30 / 10 / 1979$ & 255 & 440 & 9.73 \\
\hline $1 / 11 / 1973$ & 251 & 2345 & 50.85 & $30 / 12 / 1979$ & 112 & 220 & 2.13 \\
\hline $7 / 2 / 1974$ & 93 & 115 & 0.92 & $31 / 1 / 1980$ & 97 & 897 & 7.52 \\
\hline $21 / 2 / 1974$ & 101 & 312 & 2.72 & $6 / 3 / 1980$ & 51 & 383 & 1.69 \\
\hline $24 / 10 / 1974$ & 242 & 5142 & 107.51 & $4 / 3 / 1980$ & 92 & 173 & 1.38 \\
\hline $23 / 2 / 1974$ & 289 & 2120 & 52.94 & $30 / 4 / 1980$ & 214 & 6213 & 114.88 \\
\hline $1 / 4 / 1974$ & 110 & 374 & 3.55 & $2 / 10 / 1980$ & 68 & 143 & 0.84 \\
\hline $3 / 6 / 1974$ & 89 & 278 & 2.14 & & & & \\
\hline
\end{tabular}

Table (3-3):- Sartik Dam Reservoir Useful Life Calculation

\begin{tabular}{|c|c|c|c|c|c|c|c|}
\hline \multicolumn{2}{|c|}{ Capacity } & $\begin{array}{c}\text { Capacity- } \\
\text { inflow } \\
\text { ratio }\end{array}$ & $\%$ Te & $\begin{array}{c}\text { Average } \\
\% \mathrm{Te}\end{array}$ & $\begin{array}{c}\text { Volume of } \\
\text { sediment } \\
\left(\mathrm{m}^{3}\right)\end{array}$ & $\begin{array}{c}\text { Volume of } \\
\text { capacity } \\
\text { interval }\left(\mathrm{m}^{3}\right)\end{array}$ & Years to fill \\
\hline$\%$ & $\mathrm{~m}^{3}$ & & & & & \\
\hline 100 & $681,972,418$ & 0.09 & 85.67 & & & & 99.51 \\
\hline 90 & $613,775,177$ & 0.08 & 84.33 & 85.00 & $1,019,994$ & $101,504,336$ & 101.10 \\
\hline 80 & $545,577,935$ & 0.07 & 83.00 & 83.67 & $1,003,998$ & $101,504,336$ & 109.32 \\
\hline 70 & $477,380,693$ & 0.06 & 71.75 & 77.38 & 928,500 & $101,504,336$ & 118.41 \\
\hline 60 & $409,183,451$ & 0.055 & 71.13 & 71.44 & 857,250 & $101,504,336$ & 119.45 \\
\hline 50 & $340,986,209$ & 0.05 & 70.50 & 70.81 & 849,750 & $101,504,336$ & 121.05 \\
\hline 40 & $272,788,967$ & 0.04 & 69.25 & 69.88 & 838,500 & $101,504,336$ & 123.26 \\
\hline 30 & $204,591,726$ & 0.03 & 68.00 & 68.63 & 823,500 & $101,504,336$ & 149.71 \\
\hline 20 & $136,394,484$ & 0.02 & 68.00 & 68.00 & 816,000 & $101,504,336$ & 124.39 \\
\hline 10 & $68,197,242$ & 0.01 & 45.00 & 56.50 & 678,000 & $101,504,336$ & 1496.70 \\
\hline Total & & & & & & & 966.70 \\
\hline
\end{tabular}

\section{3-3 Reservoir Water Losses Due To Evaporation:}

The monthly and annual Evaporation losses were calculated from daily recorded evaporation using the following equation based on area, volume and elevation curve [8].

$$
\mathbf{Y}=\mathbf{a} * \mathbf{V}^{\mathbf{b}} * \mathbf{E} \quad \ldots \ldots
$$

Where, $\mathrm{Y}$ is monthly water losses from reservoir due to evaporation in $\left(\mathrm{m}^{3} / \mathrm{sec}\right), \mathrm{V}$ is water storage in the reservoir in specified month $\left(\mathrm{m}^{3}\right)$, E is monthly recorded evaporation for Dokan station in (m), and a and b are area, and volume curve equation parameters (from figure2), $\mathrm{a}=218.1$, and $\mathrm{b}=0.597$

The results of the calculations are presented in table (3-4) below: 
Table (3-4): Mean Monthly Losses Due to Evaporation from Sartik Dam Reservoir

\begin{tabular}{|c|c|c|}
\hline Month & Evaporation ( $\mathrm{mm}$ ) & Losses (m ${ }^{3} /$ month) \\
\hline Jan. & 34.1 & $1,410,246$ \\
\hline Feb. & 41.0 & $1,695,604$ \\
\hline March & 66.4 & $2,746,051$ \\
\hline April & 98.8 & $4,085,991$ \\
\hline May & 160.1 & $6,621,125$ \\
\hline June & 258.7 & $10,698,845$ \\
\hline July & 301.8 & $8,227,525$ \\
\hline Aug. & 275.5 & $5,342,794$ \\
\hline Sept. & 210.7 & $4,450,114$ \\
\hline Oct. & 118.0 & $2,391,220$ \\
\hline Nov. & 61.8 & $1,887,181$ \\
\hline Dec. & 38.1 & $1,575,671$ \\
\hline Year & 1664.9 & $51,132.366$ \\
\hline
\end{tabular}

\section{3-4 Reservoir Storages:}

From above mentioned losses calculations the Sartik proposed dam reservoir levels and storages were fixed. The dead storage elevation was provided at $\mathbf{3 0 9}$ m.a.s.l. this level gives dead storage volume equal to $\left(104,304,031 \mathrm{~m}^{3}\right)$, and the normal reservoir water level (NWL) is fixed at 325 m.a.s.l. which gives live storage capacity equal to $(384,846,885)$ and flooded area equal to $\left(34.184 \mathrm{~km}^{2}\right)$ as shown in table (3-5).

Table (3-5) :-Storages of Sartik Proposed Dam Reservoir

\begin{tabular}{|c|c|c|c|c|c|c|}
\hline \multicolumn{3}{|c|}{ Dead Storage } & \multicolumn{3}{c|}{ Live Storage } & Dam crest level \\
\hline $\begin{array}{c}\text { Level } \\
(\mathbf{m} . a . s . l)\end{array}$ & Volume $\left(\mathbf{m}^{3}\right)$ & $\begin{array}{c}\text { Flooded area } \\
\left(\mathrm{km}^{2}\right)\end{array}$ & Level (m.a.s.l) & Volume $\left(\mathbf{m}^{3}\right)$ & $\begin{array}{c}\text { Flooded area } \\
\left(\mathrm{km}^{2}\right)\end{array}$ & $(\mathrm{m}$. a.s.l) \\
\hline 309 & $104,304,031$ & 13.555 & 325 & $384,846,885$ & 34.184 & 335 \\
\hline
\end{tabular}

\section{3-5 Reservoir Simulation Model:}

The Sartik Dam consists of a multi-purpose dam for, flood control, regulation of the LowerZab River below Dokan Dam, Irrigation, and power generation. Reservoir operation is necessary to be made in such a manner that it functions according to the respective purposes of its design. At Sartik Reservoir, the storage capacity of (384.846 MCM), between normal operation water level of (325 m.a.s.l.) and minimum operation water level of (309) m.a.s.l, is to be utilized for irrigation and power generation. The operation rules for Sartik Reservoir are to be fixed on the bases of the following factors:

1. Irrigation and power generations are carried out within the range of the storage capacity of (384.846 MCM).

2. Maximum discharge from Power outlet is fixed, which is equal to $300 \mathrm{~m}^{3} / \mathrm{sec}$.

3. Operation is done in a manner that waste spillage from the reservoir is minimum.

4. High-water-level operation is performed as a rule to ensure stable output over a long period. In addition, this will maximize the energy production.
5. Operation for power generation is performed in such a manner that the necessary irrigation water is secured even in fairly dry years.

In this section, the real time monthly operation of the Sartik reservoir has been obtained by using historical monthly inflow data for the period October 1960 to September 1999. These forty years inflow data represent the input of the model. This period has been chosen because it includes the flood years 1969 and 1988, the deficit years 1989 and 1999, and the average years 1981 and 1994.

The monthly operation procedure depends on the monthly inflow data, as well as on the water demand, and evaporation data. This is an accounting of the inflow-outflow activity of the reservoir and can be stated as [4]:

Volume for next month $=$ Stored Volume + Inflow Volume - Demand Volume Evaporation losses ....... (5)

For all other months, the storage in the reservoir should belong to the set of admissible storage it means that the storage for any month should not be less than minimum storage and should not exceed range of the storage capacity of (384.846 MCM). 
Figures (3), (4), (5), (6),(7) and (8) shows the simulation model of the Sartik reservoir, prepared from calculation of water inflow into the reservoir and water demand including evaporation losses from the reservoir surface for each month .The inflow was taken for different types of water years, dry (deficit) years (1984,and 1999), average water years (1981,and1995) inflow ,and maximum (flood) water years (1969 and 1988) inflow. From the curves it is clear that the reservoir starts full at month April and ends full at month March during one year taking in account that the maximum water storage in the reservoir is $(489,150,916) \mathrm{m}^{3}$ and minimum storage is $(104,304,031) \mathrm{m}^{3}$.

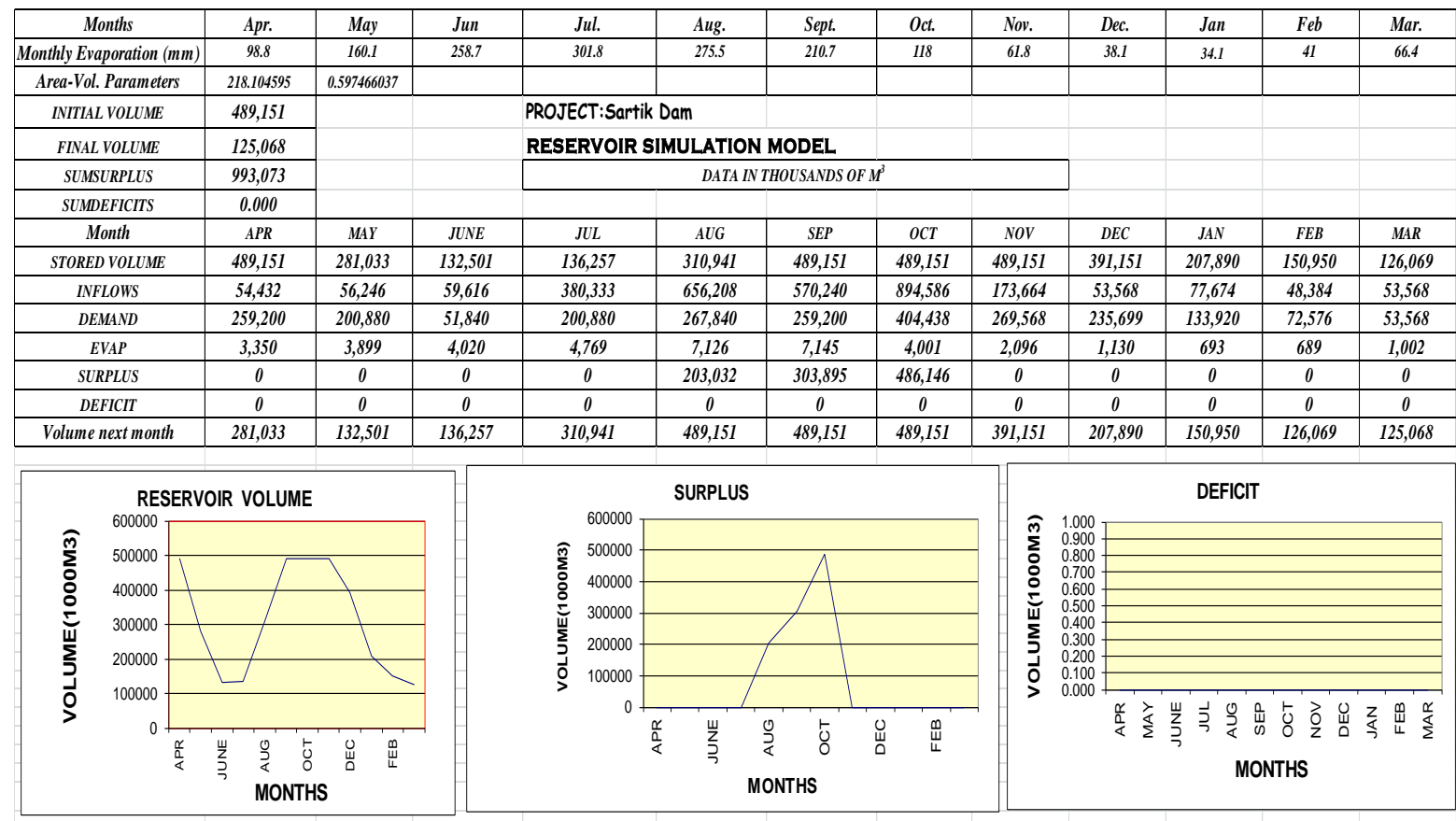

Fig. (3):- Simulation model of the Sartik reservoir for dry year inflow data (1984)

\begin{tabular}{|c|c|c|c|c|c|c|c|c|c|c|c|c|}
\hline Months & Apr. & May & Jun & Jul. & Aug. & Sept. & Oct. & Nov. & Dec. & Jan & $\mathrm{Feb}$ & Mar. \\
\hline Monthly Evaporation $(\mathrm{mm})$ & 98.8 & 160.1 & 258.7 & 301.8 & 275.5 & 210.7 & 118 & 61.8 & 38.1 & 34.1 & 41 & 66.4 \\
\hline Area-Vol. Parameters & 218.104595 & 0.597466037 & & & & & & & & & & \\
\hline INITIAL VOLUME & 489,151 & & & \multicolumn{2}{|c|}{ PROJECT:Sartik Dam } & & & & & & & \\
\hline FINAL VOLUME & $425,296.175$ & & & \multicolumn{3}{|c|}{ RESERVOIR SIMULATION MODEL } & & & & & & \\
\hline SUMSURPLUS & $1,440,107$ & & & \multicolumn{5}{|c|}{\begin{tabular}{|c|} 
DATA IN THOUSANDS OF $M^{3}$ \\
\end{tabular}} & & & & \\
\hline SUMDEFICITS & 0 & & & & & & & & & & & \\
\hline Month & $A P R$ & MAY & JUNE & $J U L$ & $A U G$ & SEP & $O C T$ & NOV & $D E C$ & $J A N$ & $F E B$ & MAR \\
\hline STORED VOLUME & 489,151 & 452,105 & 401,393 & 341,758 & 306,714 & 256,791 & 174,169 & 386,282 & 489,151 & 489,151 & 489,151 & 489,151 \\
\hline INFLOWS & 225,504 & 222,307 & 207,360 & 241,056 & 224,986 & 181,440 & 618,710 & 645,408 & 846,374 & 782,093 & 314,496 & 259,805 \\
\hline DEMAND & 259,200 & 267,840 & 259,200 & 267,840 & 267,840 & 259,200 & 404,438 & 269,568 & 235,699 & 273,197 & 261,274 & 321,408 \\
\hline EVAP & 3,350 & 5,179 & 7,795 & 8,260 & 7,068 & 4,861 & 2,159 & 1,820 & 1,292 & 1,156 & 1,390 & 2,252 \\
\hline SURPLUS & 0 & 0 & 0 & 0 & 0 & 0 & 0 & 271,152 & 609,383 & 507,740 & 51,832 & 0 \\
\hline DEFICIT & 0 & 0 & 0 & 0 & 0 & 0 & 0 & 0 & 0 & 0 & 0 & 0 \\
\hline Volume next month & 452,105 & 401,393 & 341,758 & 306,714 & 256,791 & 174,169 & 386,282 & 489,151 & 489,151 & 489,151 & 489,151 & 425,296 \\
\hline
\end{tabular}

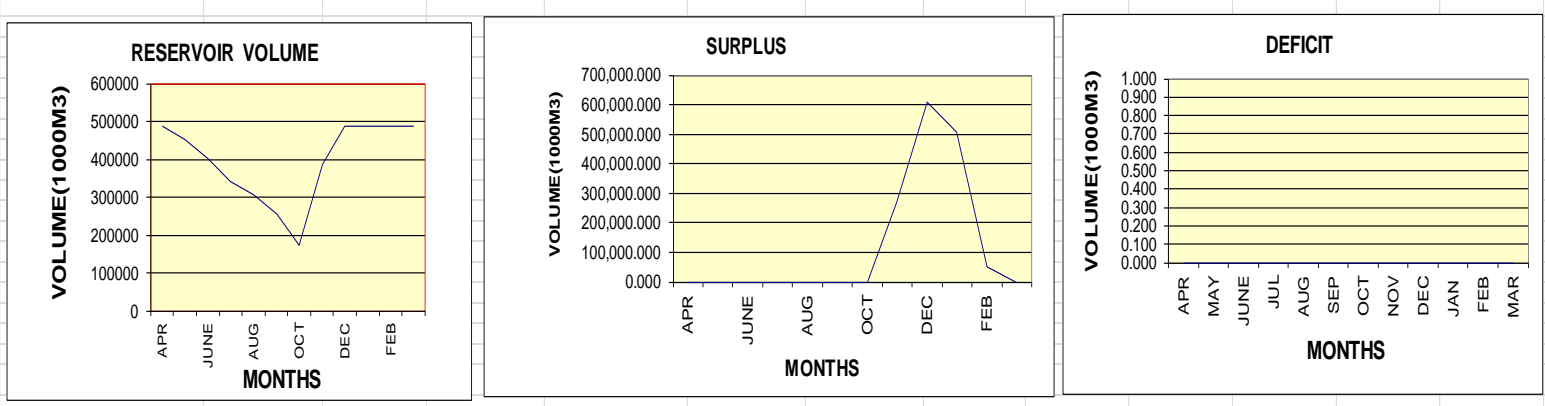

Fig.(4):- Simulation model of the Sartik reservoir for dry year inflow data (1999) 


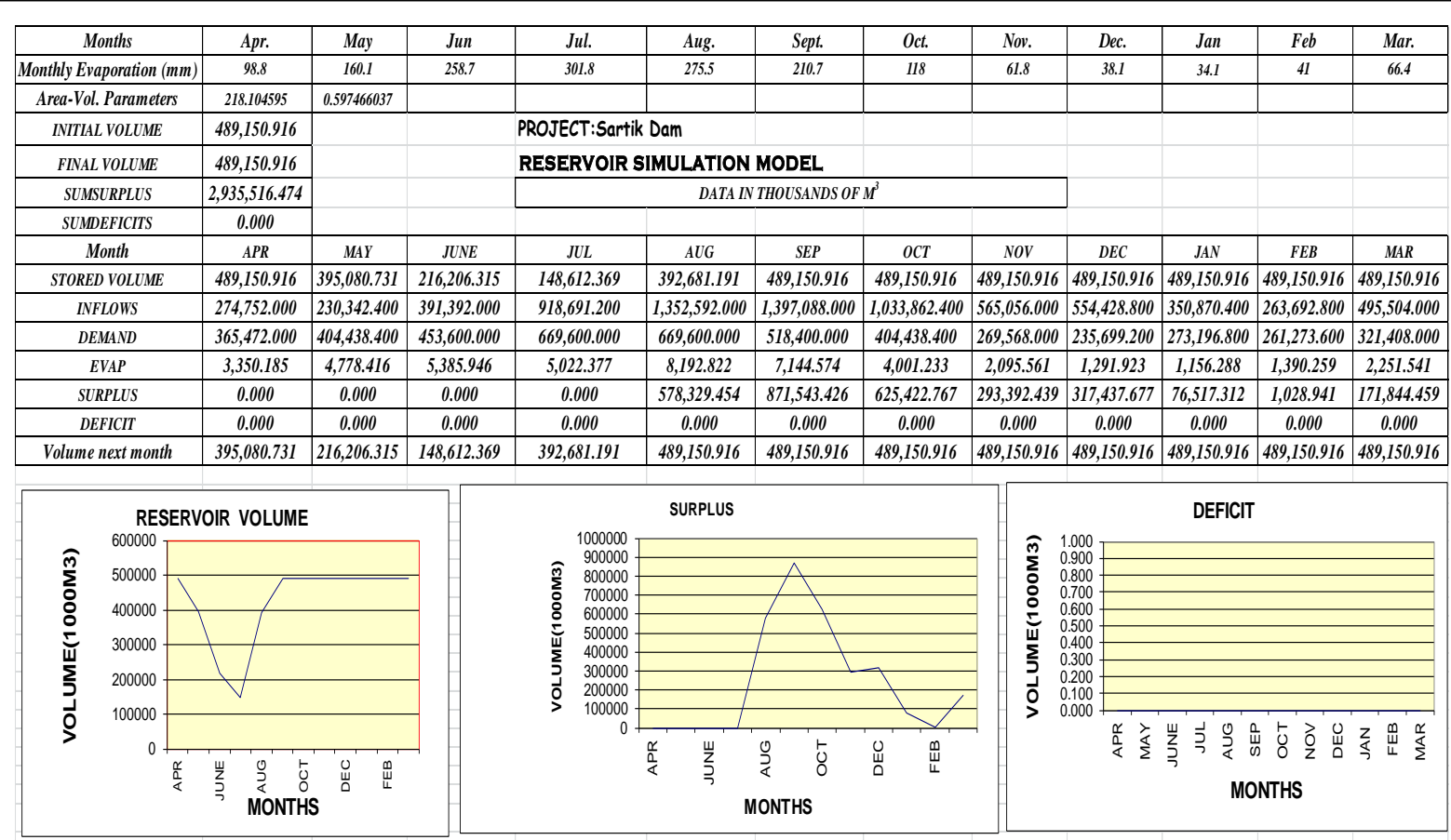

Fig. (5):- Simulation model of the Sartik reservoir for average year inflow data (1981)

\begin{tabular}{|c|c|c|c|c|c|c|c|c|c|c|c|c|}
\hline Months & Apr. & May & Jun & Jul. & Aug. & Sept. & Oct. & Nov. & Dec. & Jan & $\mathrm{Feb}$ & Mar. \\
\hline Monthly Evaporation $(\mathrm{mm})$ & 98.8 & 160.1 & 258.7 & 301.8 & 275.5 & 210.7 & 118 & 61.8 & 38.1 & 34.1 & 41 & 66.4 \\
\hline Area-Vol. Parameters & 218.104595 & 0.597466037 & & & & & & & & & & \\
\hline INITIAL VOLUME & $489,150.916$ & & & \multicolumn{2}{|c|}{ PROJECT:Sartik Dam } & & & & & & & \\
\hline FINAL VOLUME & $489,150.916$ & & & \multicolumn{3}{|c|}{ RESERVOIR SIMULATION MODEL } & & & & & & \\
\hline SUMSURPLUS & $1,758,542.269$ & & & \multicolumn{5}{|c|}{\begin{tabular}{|r|r|r|} 
DATA IN THOUSANDS OF $M^{3}$ \\
\end{tabular}} & & & & \\
\hline SUMDEFICITS & 0.000 & & & & & & & & & & & \\
\hline STORED VOLUME & $489,150.916$ & $489,150.916$ & $489,150.916$ & $353,370.722$ & $202,988.745$ & $253,711.589$ & $222,965.034$ & $402,593.961$ & $489,150.916$ & $489,150.916$ & $489,150.916$ & $489,150.916$ \\
\hline INFLOWS & $461,376.000$ & $474,076.800$ & $520,992.000$ & $661,564.800$ & $591,926.400$ & $492,480.000$ & $586,569.600$ & $780,192.000$ & $474,076.800$ & $629,424.000$ & $619,315.200$ & $554,428.800$ \\
\hline DEMAND & $365,472.000$ & $404,438.400$ & $648,000.000$ & $803,520.000$ & $535,680.000$ & $518,400.000$ & $404,438.400$ & $269,568.000$ & $235,699.200$ & $273,196.800$ & $261,273.600$ & $321,408.000$ \\
\hline EVAP & $3,350.185$ & \begin{tabular}{|l}
$5,428.791$ \\
\end{tabular} & $8,772.194$ & $8,426.777$ & $5,523.556$ & $4,826.555$ & $2,502.273$ & $1,865.388$ & 1,291.923 & $1,156.288$ & $\begin{array}{l}1,390.259 \\
\end{array}$ & $2,251.541$ \\
\hline SURPLUS & $92,553.815$ & $64,209.609$ & 0.000 & 0.000 & 0.000 & 0.000 & 0.000 & $422,201.657$ & $237,085.677$ & $355,070.912$ & $356,651.341$ & $230,769.259$ \\
\hline DEFICIT & 0.000 & \begin{tabular}{|l|}
0.000 \\
\end{tabular} & 0.000 & 0.000 & 0.000 & 0.000 & \begin{tabular}{|l|}
0.000 \\
\end{tabular} & 0.000 & 0.000 & 0.000 & 0.000 & $\begin{array}{l}0.000 \\
\end{array}$ \\
\hline
\end{tabular}
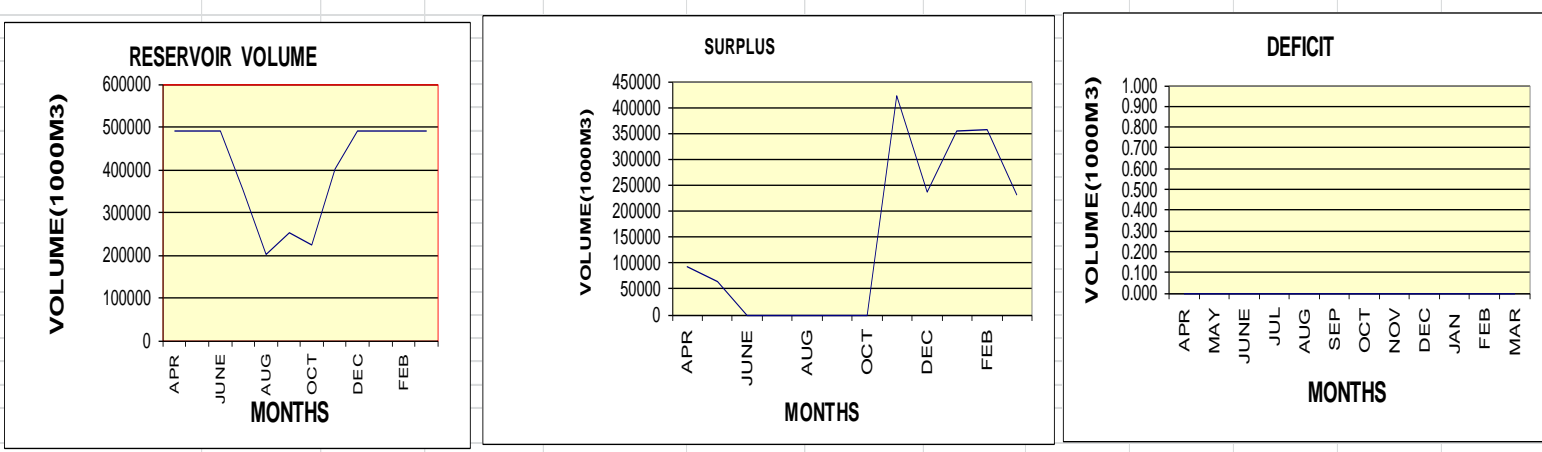

Fig. (6):- Simulation model of the Sartik reservoir for average year inflow data (1995) 


\begin{tabular}{|c|c|c|c|c|c|c|c|c|c|c|c|c|}
\hline Months & Apr. & May & Jun & Jul. & Aug. & Sept. & Oct. & Nov. & Dec. & Jan & Feb & Mar. \\
\hline Monthly Evaporation (mm) & 98.8 & 160.1 & 258.7 & 301.8 & 275.5 & 210.7 & 118 & 61.8 & 38.1 & 34.1 & 41 & 66.4 \\
\hline Area-Vol. Parameters & 218.104595 & 0.597466037 & & & & & & & & & & \\
\hline INITIAL VOLUME & $489,150.916$ & & & \multicolumn{2}{|c|}{ PROJECT:Sartik Dam } & & & & & & & \\
\hline FINAL VOLUME & $489,150.916$ & & & \multicolumn{3}{|c|}{ RESERVOIR SIMULATION MODEL } & & & & & & \\
\hline SUMSURPLUS & $10,336,789.066$ & & & \multicolumn{5}{|c|}{ DATA IN THOUSANDS OF $M^{3}$} & & & & \\
\hline SUMDEFICITS & 0.000 & & & & & & & & & & & \\
\hline Month & APR & MAY & JUNE & $\mathrm{JUL}$ & AUG & SEP & ост & NOV & DEC & JAN & FEB & MAR \\
\hline STORED VOLUME & $489,150.916$ & $489,150.916$ & $489,150.916$ & $433,722.722$ & $489,150.916$ & $489,150.916$ & $489,150.916$ & $489,150.916$ & $489,150.916$ & $489,150.916$ & $489,150.916$ & $489,150.916$ \\
\hline INFLOWS & $3,696,192.000$ & $1,952,553.600$ & $730,944.000$ & $1,315,094.400$ & $1,848,096.000$ & $977,184.000$ & $583,891.200$ & $505,440.000$ & $527,644.800$ & $557,107.200$ & $1,175,731.200$ & $2,220,393.600$ \\
\hline DEMAND & $365,472.000$ & $404,438.400$ & $777,600.000$ & $803,520.000$ & $803,520.000$ & $777,600.000$ & $404,438.400$ & $269,568.000$ & $235,699.200$ & $273,196.800$ & $261,273.600$ & $321,408.000$ \\
\hline EVAP & $3,350.185$ & $5,428.791$ & $8,772.194$ & $9,524.123$ & $9,341.861$ & $7,144.574$ & $4,001.233$ & \begin{tabular}{|l|}
$2,095.561$ \\
\end{tabular} & \begin{tabular}{|l|}
$1,291.923$ \\
\end{tabular} & \begin{tabular}{|l|}
$1,156.288$ \\
\end{tabular} & $1,390.259$ & $2,251.541$ \\
\hline SURPLUS & $3,327,369.815$ & $1,542,686.409$ & 0.000 & $446,622.083$ & $1,035,234.139$ & $192,439.426$ & $175,451.567$ & $233,776.439$ & $290,653.677$ & $282,754.112$ & $913,067.341$ & $1,896,734.059$ \\
\hline DEFICIT & 0.000 & 0.000 & 0.000 & 0.000 & 0.000 & 0.000 & 0.000 & \begin{tabular}{|l|}
0.000 \\
\end{tabular} & 0.000 & 0.000 & 0.000 & 0.000 \\
\hline Volume next month & $489,150.916$ & $489,150.916$ & $433,722.722$ & $489,150.916$ & $489,150.916$ & $489,150.916$ & \begin{tabular}{|l|}
$489,150.916$ \\
\end{tabular} & $489,150.916$ & $489,150.916$ & $489,150.916$ & $489,150.916$ & $489,150.916$ \\
\hline
\end{tabular}
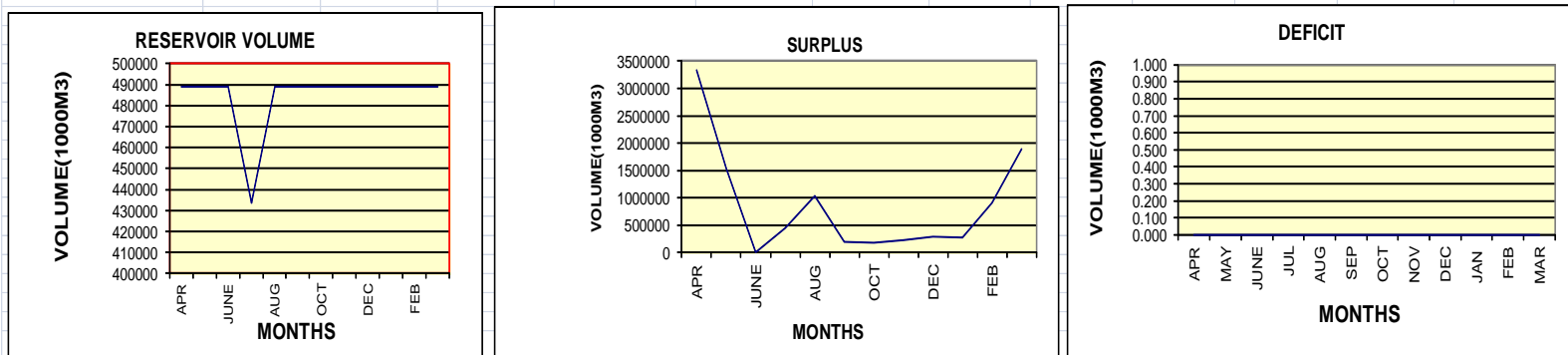

Fig. (7): Simulation model of the Sartik reservoir for wet year inflow data (1969)

\begin{tabular}{|c|c|c|c|c|c|c|c|c|c|c|c|c|}
\hline Months & Apr. & May & Jun & Jul. & Aug. & Sept. & Oct. & Nov. & Dec. & Jan & $F e b$ & Mar. \\
\hline Monthly Evaporation (mm) & 98.8 & 160.1 & 258.7 & 301.8 & 275.5 & 210.7 & 118 & 61.8 & 38.1 & 34.1 & 41 & 66.4 \\
\hline Area-Vol. Parameters & 218.104595 & 0.597466037 & & & & & & & & & & \\
\hline INITIAL VOLUME & $489,150.916$ & & & \multicolumn{2}{|c|}{ PROJECT:Sartik Dam } & & & & & & & \\
\hline FINAL VOLUME & $489,150.916$ & & & \multicolumn{3}{|c|}{ RESERVOIR SIMULATION MODEL } & & & & & & \\
\hline SUMSURPLUS & $10,809,724.327$ & & & \multicolumn{5}{|c|}{ DATA IN THOUSANDS OF $M^{3}$} & & & & \\
\hline SUMDEFICITS & 0.000 & & & & & & & & & & & \\
\hline Month & $A P R$ & MAY & JUNE & $J U L$ & $A U G$ & SEP & $O C T$ & $\mathrm{NOV}$ & $D E C$ & JAN & FEB & MAR \\
\hline STORED VOLUME & $489,150.916$ & $489,150.916$ & $489,150.916$ & $489,150.916$ & $489,150.916$ & $489,150.916$ & $489,150.916$ & $489,150.916$ & $489,150.916$ & $489,150.916$ & $489,150.916$ & $489,150.916$ \\
\hline INFLOWS & $1,998,086.400$ & $1,738,281.600$ & $1,137,888.000$ & $1,328,486.400$ & $1,475,798.400$ & $1,342,656.000$ & $784,771.200$ & $539,136.000$ & $712,454.400$ & $514,252.800$ & $1,153,958.400$ & $3,838,147.200$ \\
\hline DEMAND & $365,472.000$ & $404,438.400$ & $777,600.000$ & $803,520.000$ & $803,520.000$ & $777,600.000$ & $404,438.400$ & $269,568.000$ & $235,699.200$ & $273,196.800$ & $261,273.600$ & $321,408.000$ \\
\hline EVAP & $3,350.185$ & $5,428.791$ & $8,772.194$ & $10,233.661$ & $9,341.861$ & 7,144.574 & $4,001.233$ & \begin{tabular}{|l|}
$2,095.561$ \\
\end{tabular} & 1,291.923 & $1,156.288$ & $1,390.259$ & $2,251.541$ \\
\hline SURPLUS & $1,629,264.215$ & $1,328,414.409$ & $351,515.806$ & $514,732.739$ & $662,936.539$ & $557,911.426$ & $376,331.567$ & $267,472.439$ & $475,463.277$ & $239,899.712$ & $891,294.541$ & $3,514,487.659$ \\
\hline DEFICIT & 0.000 & 0.000 & 0.000 & 0.000 & 0.000 & 0.000 & 0.000 & \begin{tabular}{|l|l|}
0.000 \\
\end{tabular} & 0.000 & 0.000 & 0.000 & 0.000 \\
\hline Volume next month & $489,150.916$ & $489,150.916$ & $489,150.916$ & $489,150.916$ & $489,150.916$ & $489,150.916$ & $489,150.916$ & $489,150.916$ & $489,150.916$ & $489,150.916$ & $489,150.916$ & $489,150.916$ \\
\hline
\end{tabular}
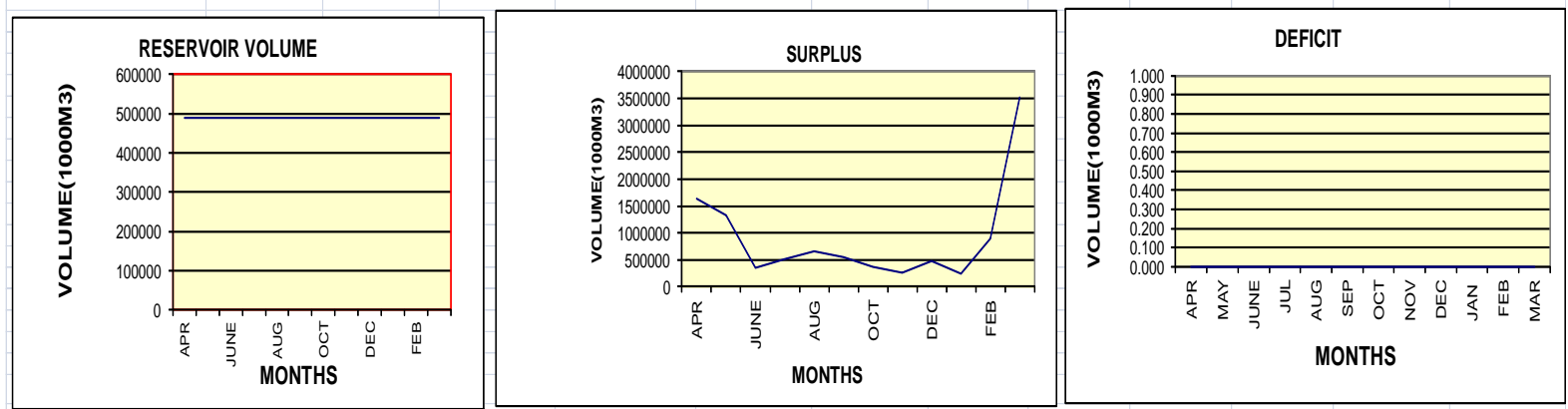

Fig. (8): Simulation model of the Sartik reservoir for wet year inflow data (1988)

\section{RESERVOIR FLOOD ROUTING}

The flood routing was used to check the maximum head over the spillway weir crest and to

$$
\left(\frac{2 S_{n+1}}{d_{t}}+O_{n+1}\right)=I_{n}+I_{n+1}+\left(\frac{2 S_{n}}{d_{t}}-O_{n}\right)
$$

Where: $\mathrm{dt}$ is routing time interval $(6 \mathrm{hrs}), \mathrm{I}_{\mathrm{n}}$ is inflow discharge $\left(\mathrm{m}^{3} / \mathrm{sec}\right)$ at time $\mathrm{t}, \mathrm{I}_{\mathrm{n}+1}$ is inflow find the routed outflow discharge over the spillway crest using puls method, equation(4) [8] . 
discharge $\left(\mathrm{m}^{3} / \mathrm{sec}\right)$ at time $(\mathrm{t}+\mathrm{dt}), \mathrm{S}_{\mathrm{n}}$ is reservoir storage $\left(\mathrm{m}^{3}\right)$ at time $t$, and $S_{n+1}$ is reservoir storage $\left(\mathrm{m}^{3}\right)$ at time $(\mathrm{t}+\mathrm{dt})$

The flood routing study was done using the following data:-

1. The crest level of ogee spillway will be fixed at 320 m.a.s.l. as shown in the figure (9).

2. Number of gated spans $=7$ and the length of each $\operatorname{span}=12 \mathrm{~m}$.

3. Initial water level of the reservoir is 325 m.a.s.l.

4. The (PMF, 1000, 100, 50, and 25) years return periods inflow hydrographs of Sartik dam site are to be used.
5. Stage and volume curve, which is given in the figure (1) are to be used.

6. The results of this routing are used to determine the design parameters of the spillway and to determine the actual need of the emergency spillway.

Spillway discharge capacity for free overflow is presented in the following figure (10) and discharge capacity for different partial openings of gates $(Y)$ is presented in the following table (3-6).

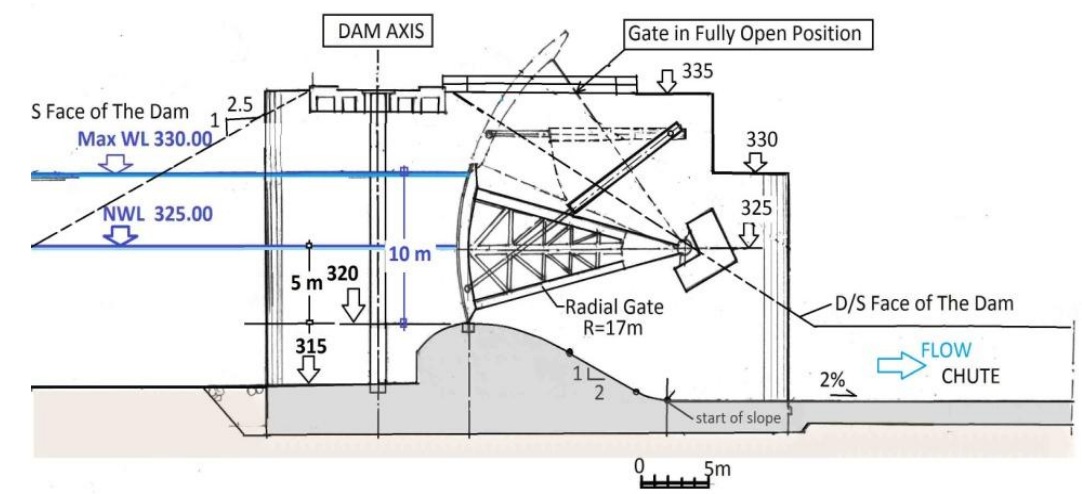

Fig. (9):-Sartik Dam Spillway Radial Gate Elevations
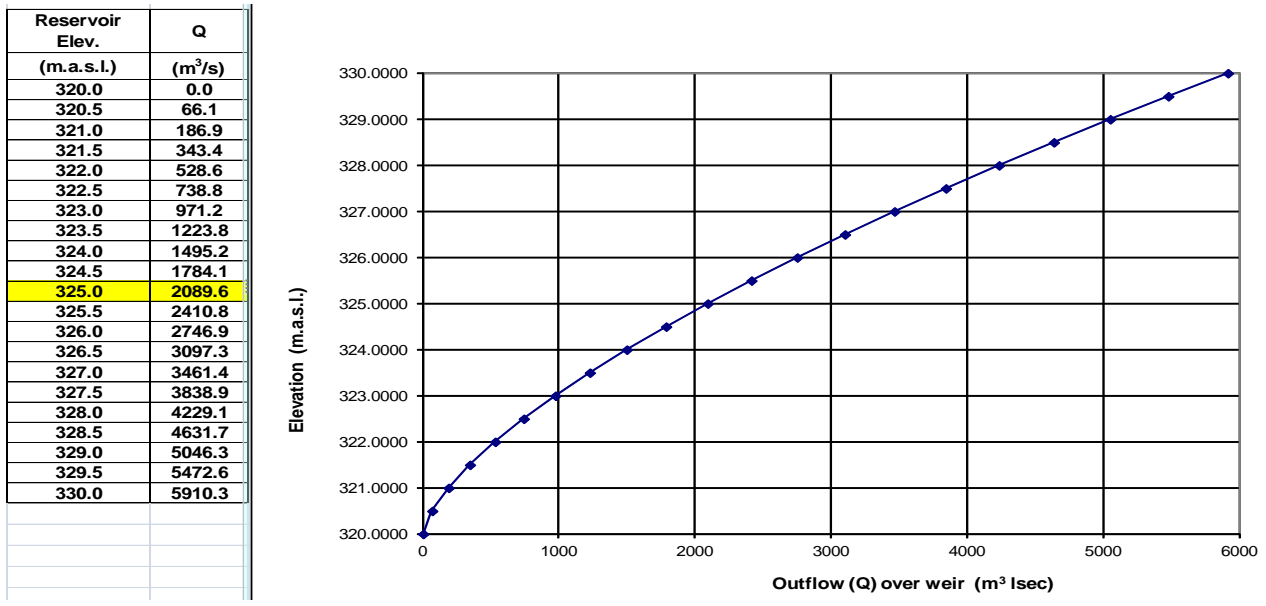

Fig. (10):- Sartik Dam Spillway Free Flow Discharge VS Elevation 


\begin{tabular}{|c|c|c|c|c|c|c|c|c|c|c|}
\hline \multirow{2}{*}{$\begin{array}{c}\text { Reservoir } \\
\text { Elev. } \\
\text { (m.a.s.l.) }\end{array}$} & \multicolumn{10}{|c|}{ Gates Opening $(\mathrm{Y})(\mathrm{m})$} \\
\hline & 1.0 & 2.0 & 3.0 & 4.0 & 5.0 & 6.0 & 7.0 & 8.0 & 9.0 & 10.0 \\
\hline 320.0 & & & & & & & & & & \\
\hline 320.5 & 66.1 & 66.1 & & & & & & & & \\
\hline 321.0 & 186.9 & 186.9 & & & & & & & & \\
\hline 321.5 & 228.9 & 343.4 & & \multirow{2}{*}{\multicolumn{4}{|c|}{ free overflow discharge zone }} & & & \\
\hline 322.0 & 264.3 & 528.6 & & & & & & & & \\
\hline 322.5 & 295.5 & 591.0 & & & & & & & & \\
\hline 323.0 & 323.7 & 647.4 & 971.1 & & & & & & & \\
\hline 323.5 & 349.6 & 699.3 & 1048.9 & & & & & & & \\
\hline 324.0 & $\begin{array}{l}343.0 \\
373.8\end{array}$ & 747.6 & 1040.5 & 1495.1 & & & & & & \\
\hline 324.5 & 396.5 & 792.9 & 1189.4 & 1585.8 & & & & & & \\
\hline 325.0 & 417.9 & 835.8 & 1253.7 & 1671.6 & 2089.5 & & & & & \\
\hline 325.5 & 438.3 & 876.6 & 1314.9 & 1753.2 & 2191.5 & & & & & \\
\hline 326.0 & 457.8 & 915.6 & 1373.4 & 1831.2 & 2289.0 & 2746.7 & & & & \\
\hline 326.5 & 476.5 & 953.0 & 1429.5 & 1905.9 & 2382.4 & 2858.9 & & & & \\
\hline 327.0 & 494.5 & 988.9 & 1483.4 & 1977.9 & 2472.4 & 2966.8 & 3461.3 & & & \\
\hline 327.5 & 511.8 & 1023.7 & 1535.5 & 2047.3 & 2559.1 & 3071.0 & 3582.8 & & & \\
\hline 328.0 & 528.6 & 1057.2 & 1585.8 & 2114.4 & 2643.1 & 3171.7 & 3700.3 & 4228.9 & & \\
\hline 328.5 & 544.9 & 1089.8 & 1634.6 & 2179.5 & 2724.4 & 3269.3 & 3814.2 & 4359.0 & & \\
\hline $\begin{array}{l}329.0 \\
329.0\end{array}$ & 560.7 & 1005.0 & 1634.0 & 2242.7 & 2803.4 & $\begin{array}{l}3205.0 \\
3364.1\end{array}$ & $\begin{array}{l}3014.2 \\
3924.7\end{array}$ & $\begin{array}{l}4485.4 \\
4485.4\end{array}$ & 5046.1 & \\
\hline 329.5 & 576.0 & 1152.1 & 1728.1 & 2304.2 & 2880.2 & 3456.2 & 4032.3 & 4608.3 & 5184.4 & \\
\hline 330.0 & 591.0 & 1182.0 & 1773.0 & 2364.0 & 2532.9 & 3546.0 & 4137.0 & 4728.0 & 5319.1 & 5910.1 \\
\hline
\end{tabular}

Table (3-6):- Sartik Dam Spillway Discharge capacity for Partial Opening Gates (Orifice Flow)

For the case of flood coming into the Sartik reservoir, radial gates will start opening keeping the water level at NWL (325 m.a.s.l.). After the full opening of the radial gates the water level will continue rising till the Maximum Water Level (MWL).The maximum water level during the flood routing should not go beyond the level of $330 \mathrm{~m}$ because of the level Taq Taq bridge and the main road at upstream, if we passed this level the bridge and the road will submerged.

Results of PMF ,1000,100,50 and 25 years return periods flood routing through the reservoir are presented in two types of figures the first is inflow and resulting outflow hydrographs figures (11-a),(12-a),(13-a),(14-a),and (15-a). The second is water level fluctuation in the reservoir with the

Table (3-7): Sartik Dam Inflow, Outflow, and Water levels For PMF flood routing

\begin{tabular}{|c|c|c|c|c|c|}
\hline $\mathrm{T}(\mathrm{hr})$ & $\begin{array}{l}\text { inflow } \\
(\mathrm{m} 3 / \mathrm{s})\end{array}$ & $\begin{array}{l}\text { outflow } \\
\text { (m3/s) }\end{array}$ & $\begin{array}{l}\text { Elevation } \\
\text { (m a.s.I.) }\end{array}$ & $\begin{array}{l}\text { Head } \\
\text { over } \\
\text { spillway } \\
\text { (m) }\end{array}$ & $\begin{array}{l}\text { Gate } \\
\text { opening } \\
\text { (m) }\end{array}$ \\
\hline 6 & 628 & 1737.39 & 324.48 & 4.48 & 10 \\
\hline 12 & 889 & 1501.04 & 324.06 & 4.06 & 10 \\
\hline 18 & 2092 & 1337.64 & 323.76 & 3.76 & 10 \\
\hline 24 & 5753 & 1277.15 & 323.65 & 3.65 & 10 \\
\hline 30 & 8368 & 1598.25 & 324.24 & 4.24 & 10 \\
\hline 36 & 9100 & 2727.18 & 326.05 & 6.05 & 10 \\
\hline 42 & 8472 & 4149.2 & 328.01 & 8.01 & 10 \\
\hline 48 & 7322 & 5294.93 & 329.42 & 9.42 & 10 \\
\hline 54 & 5962 & 6271.39 & 330.15 & 10.15 & 10 \\
\hline 60 & 4393 & 6456.42 & 330.21 & 10.21 & 10 \\
\hline 66 & 3452 & 5745.47 & 329.95 & 9.95 & 10 \\
\hline 72 & 2406 & 5327.9 & 329.46 & 9.46 & 10 \\
\hline 78 & 1674 & 4798.33 & 328.82 & 8.82 & 10 \\
\hline 84 & 1151 & 4201 & 328.07 & 8.07 & 10 \\
\hline 90 & 732 & 3604.72 & 327.29 & 7.29 & 10 \\
\hline 96 & 523 & 3046.31 & 326.51 & 6.51 & 10 \\
\hline 102 & 314 & 2541.13 & 325.77 & 5.77 & 10 \\
\hline 108 & 209 & 2112.35 & 325.1 & 5.1 & 10 \\
\hline 114 & 157 & 1748.06 & 324.5 & 4.5 & 10 \\
\hline 120 & 105 & 1448.9 & 323.97 & 3.97 & 10 \\
\hline
\end{tabular}

time during flood routing figures (11-b), (12-b), (13-b), (14-b), and (15-b)

Coordinates of inflow, outflow, water level, head over spillway weir, and spillway gates opining of each time period flood routing are shown in tables (3-7), (3-8), (3-9), (3-10)and (3-11).

The probable maximum (PMF) Flood routing results as shown in above mentioned figures (11a),(11-b) and table (3-7) showed that the maximum outflow from Sartik reservoir was $\left(6456.42 \mathrm{~m}^{3} / \mathrm{s}\right)$, and maximum elevation reached 330.21 m.a.s.l. which is somewhat higher than 330 m.a.s.l. ,the difference $21 \mathrm{~cm}$ is not significant if covered the Taq Taq bridge and this elevation occurs only during PMF, we can increase number of gates to 8 gates instead 7 but economically 7 gates needs less cost.

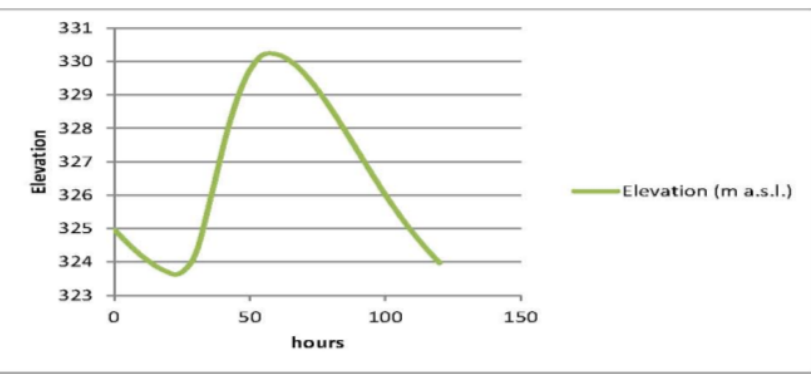

Fig.( 11-a ) : PMF Flood Time \& Water Elevation relation for Sartik Dam Spillway

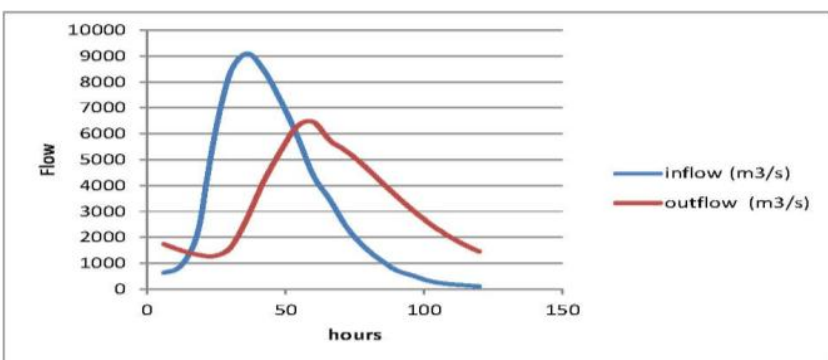

Fig.( 11 - b ) : PMF Flood Inflow \& Outflow Hydrographs $\&$ Water Level for Sartik Dam Spillway 
Table (3-8): Sartik Dam Inflow, Outflow, and Water levels for 1000 year return period flood routing

\begin{tabular}{|c|c|c|c|c|c|}
\hline $\mathrm{T}(\mathrm{hr})$ & $\begin{array}{c}\text { Inflow } \\
\left(\mathrm{m}^{3} / \mathrm{s}\right)\end{array}$ & $\begin{array}{c}\text { Outflow } \\
\left(\mathrm{m}^{3} / \mathrm{s}\right)\end{array}$ & $\begin{array}{c}\text { Reservoir } \\
\text { Elevation } \\
\text { (m.a.s.l.) }\end{array}$ & $\begin{array}{c}\text { Head over } \\
\text { weir }(\mathrm{H}) \\
(\mathrm{m})\end{array}$ & $\begin{array}{c}\text { Gate } \\
\text { Opening } \\
(\mathrm{Y})(\mathrm{m})\end{array}$ \\
\hline 0 & 100.0 & 100.0 & 325.0 & 5.0 & 6.0 \\
\hline 6 & 200.0 & 100.0 & 325.0 & 5.0 & 6.0 \\
\hline 12 & 360.0 & 150.0 & 325.0 & 5.0 & 6.0 \\
\hline 18 & 1100.0 & 300.0 & 325.0 & 5.0 & 6.0 \\
\hline 24 & 2560.0 & 1000.0 & 325.7 & 5.7 & 6.0 \\
\hline 30 & 3800.0 & 2000.0 & 326.8 & 6.8 & 6.0 \\
\hline 36 & 4100.0 & 2500.0 & 327.7 & 7.7 & 6.0 \\
\hline 42 & 3900.0 & 2650.0 & 328.3 & 8.3 & 6.0 \\
\hline 48 & 3280.0 & 2750.0 & 328.8 & 8.8 & 6.0 \\
\hline 54 & 2620.0 & 2600.0 & 328.9 & 8.9 & 6.0 \\
\hline 60 & 2050.0 & 2300.0 & 328.7 & 8.7 & 6.0 \\
\hline 66 & 1520.0 & 2000.0 & 328.5 & 8.5 & 6.0 \\
\hline 72 & 1075.0 & 1700.0 & 328.2 & 8.2 & 6.0 \\
\hline 78 & 770.0 & 1500.0 & 327.8 & 7.8 & 6.0 \\
\hline 84 & 540.0 & 1250.0 & 327.5 & 7.5 & 6.0 \\
\hline 90 & 400.0 & 1100.0 & 327.1 & 7.1 & 6.0 \\
\hline 96 & 260.0 & 900.0 & 326.7 & 6.7 & 6.0 \\
\hline 102 & 165.0 & 800.0 & 326.4 & 6.4 & 6.0 \\
\hline 108 & 110.0 & 750.0 & 326.1 & 6.1 & 6.0 \\
\hline 114 & 90.0 & 700.0 & 325.8 & 5.8 & 6.0 \\
\hline 120 & 50.0 & 650.0 & 325.4 & 5.4 & 6.0 \\
\hline & & & & & \\
\hline
\end{tabular}

Table (3-9): Sartik Dam Inflow, Outflow, and Water levels for 100 year return period flood routing

\begin{tabular}{|c|c|c|c|c|c}
\hline T (hr) & $\begin{array}{c}\text { Inflow } \\
\left(\mathrm{m}^{3} / \mathrm{s}\right)\end{array}$ & $\begin{array}{c}\text { Outflow } \\
\left(\mathrm{m}^{3} / \mathrm{s}\right)\end{array}$ & $\begin{array}{c}\text { Reservoir } \\
\text { Elevation } \\
\text { (m.a.s.l.) }\end{array}$ & $\begin{array}{c}\text { Head over } \\
\text { weir }(\mathrm{H}) \\
(\mathrm{m})\end{array}$ & $\begin{array}{c}\text { Gate } \\
\text { Opening } \\
(\mathrm{Y})(\mathrm{m})\end{array}$ \\
\hline 0 & 100.0 & 100.0 & 325.0 & 5.0 & 3.5 \\
\hline 6 & 150.0 & 150.0 & 325.0 & 5.0 & 3.5 \\
\hline 12 & 300.0 & 300.0 & 325.0 & 5.0 & 3.5 \\
\hline 18 & 750.0 & 500.0 & 325.0 & 5.0 & 3.5 \\
\hline 24 & 1800.0 & 1000.0 & 325.1 & 5.1 & 3.5 \\
\hline 30 & 2600.0 & 1300.0 & 325.7 & 5.7 & 3.5 \\
\hline 36 & 2850.0 & 1600.0 & 326.4 & 6.4 & 3.5 \\
\hline 42 & 2700.0 & 1750.0 & 327.0 & 7.0 & 3.5 \\
\hline 48 & 2300.0 & 1700.0 & 327.3 & 7.3 & 3.5 \\
\hline 54 & 1825.0 & 1600.0 & 327.5 & 7.5 & 3.5 \\
\hline 60 & 1430.0 & 1500.0 & 327.5 & 7.5 & 3.5 \\
\hline 66 & 1050.0 & 1400.0 & 327.4 & 7.4 & 3.5 \\
\hline 72 & 700.0 & 1250.0 & 327.1 & 7.1 & 3.5 \\
\hline 78 & 500.0 & 1100.0 & 326.8 & 6.8 & 3.5 \\
\hline 84 & 350.0 & 900.0 & 326.5 & 6.5 & 3.5 \\
\hline 90 & 250.0 & 700.0 & 326.2 & 6.2 & 3.5 \\
\hline 96 & 180.0 & 600.0 & 325.9 & 5.9 & 3.5 \\
\hline 102 & 100.0 & 500.0 & 325.7 & 5.7 & 3.5 \\
\hline 108 & 80.0 & 400.0 & 325.5 & 5.5 & 3.5 \\
\hline 114 & 50.0 & 300.0 & 325.4 & 5.4 & 3.5 \\
\hline 120 & 25.0 & 200.0 & 325.2 & 5.2 & 3.5 \\
\hline & & & & & \\
\hline
\end{tabular}

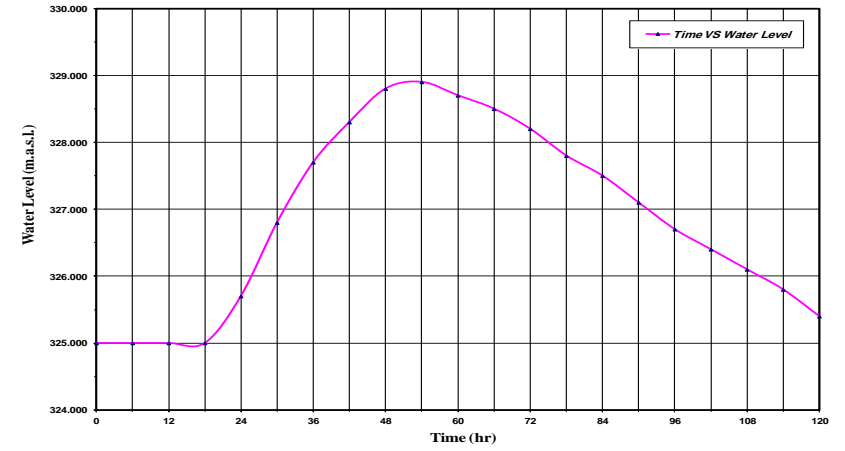

Fig.( 12-a ) : 1000 Years Return Period Flood Time \& Water Elevation relation for Sartik Dam Spillway

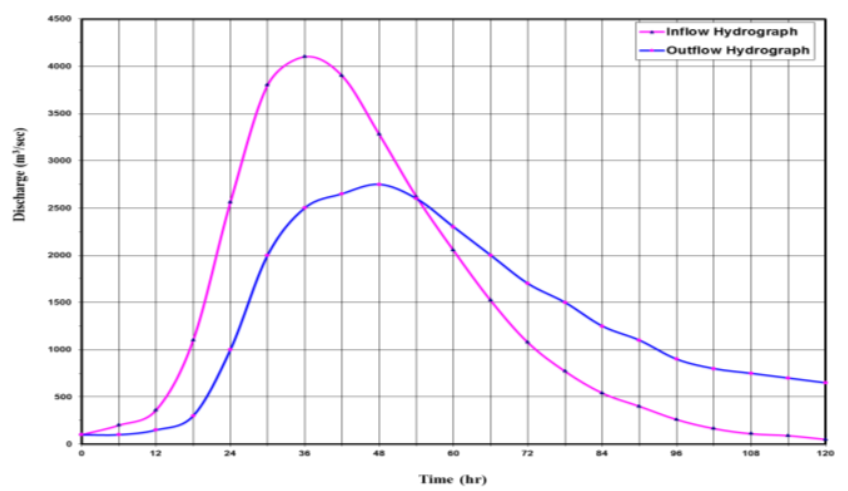

Fig. 12 - b ) : 1000 Years Return Period Flood Inflow \& Outflow Hydrographs for Sartik Dam Spillway

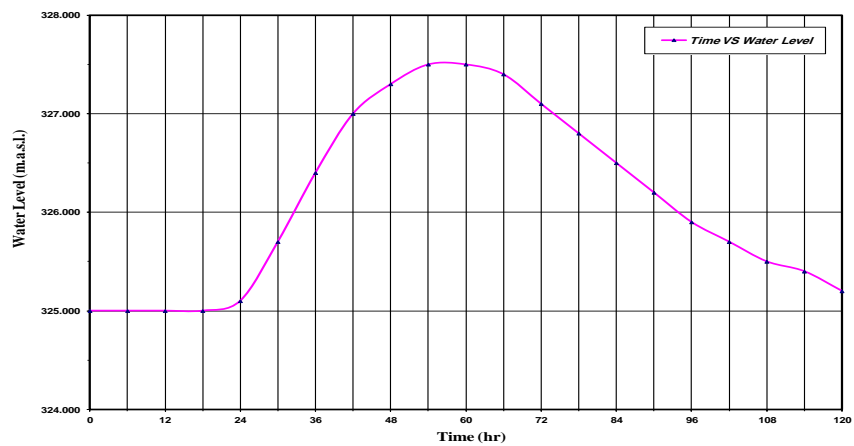

Fig.( 13-a ) : 100 Years Return Period Flood Time \& Water Elevation relation for Sartik Dam Spillway

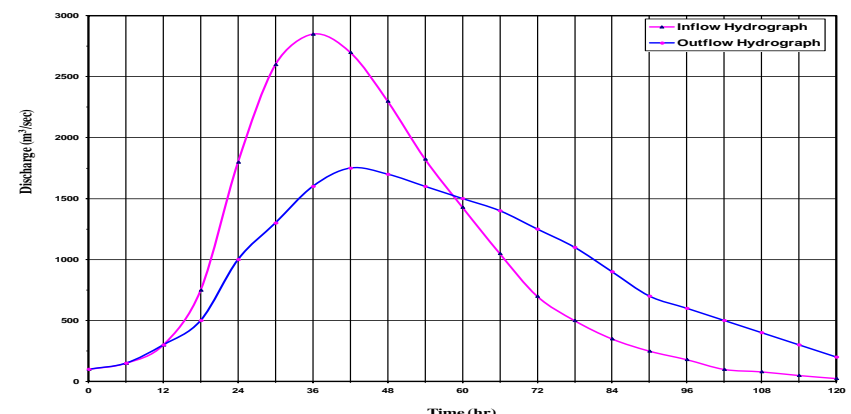

Fig.( 13 - b ) : 100 Years Return Period Flood Inflow \& Outflow Hydrographs for Sartik Dam Spillway 
Table (3-10): Sartik Dam Inflow, Outflow, and Water levels for 50 years return period flood routing

\begin{tabular}{|c|c|c|c|c|c|}
\hline $\mathrm{T}(\mathrm{hr})$ & $\begin{array}{c}\text { Inflow } \\
\left(\mathrm{m}^{3} / \mathrm{s}\right)\end{array}$ & $\begin{array}{c}\text { Outflow } \\
\left(\mathrm{m}^{3} / \mathrm{s}\right)\end{array}$ & $\begin{array}{c}\text { Reservoir } \\
\text { Elevation } \\
(\text { m.a.s.l. })\end{array}$ & $\begin{array}{c}\text { Head over } \\
\text { weir }(\mathrm{H}) \\
(\mathrm{m})\end{array}$ & $\begin{array}{c}\text { Gate } \\
\text { Opening } \\
(\mathrm{Y})(\mathrm{m})\end{array}$ \\
\hline 0 & 95.0 & 50.0 & 325.0 & 5.0 & 3.0 \\
\hline 6 & 190.0 & 50.0 & 325.0 & 5.0 & 3.0 \\
\hline 12 & 280.0 & 100.0 & 325.0 & 5.0 & 3.0 \\
\hline 18 & 560.0 & 400.0 & 325.0 & 5.0 & 3.0 \\
\hline 24 & 1435.0 & 800.0 & 325.1 & 5.1 & 3.0 \\
\hline 30 & 2130.0 & 1000.0 & 325.7 & 5.6 & 3.0 \\
\hline 36 & 2330.0 & 1200.0 & 326.0 & 6.2 & 3.0 \\
\hline 42 & 2175.0 & 1300.0 & 326.7 & 6.7 & 3.0 \\
\hline 48 & 1850.0 & 1250.0 & 327.0 & 7.0 & 3.0 \\
\hline 54 & 1435.0 & 1200.0 & 327.0 & 7.2 & 3.0 \\
\hline 60 & 1110.0 & 1100.0 & 327.0 & 7.3 & 3.0 \\
\hline 66 & 835.0 & 1000.0 & 326.8 & 7.2 & 3.0 \\
\hline 72 & 580.0 & 900.0 & 326.5 & 7.0 & 3.0 \\
\hline 78 & 395.0 & 800.0 & 326.3 & 6.9 & 3.0 \\
\hline 84 & 280.0 & 750.0 & 326.0 & 6.7 & 3.0 \\
\hline 90 & 190.0 & 700.0 & 325.6 & 6.4 & 3.0 \\
\hline 96 & 120.0 & 650.0 & 325.4 & 6.2 & 3.0 \\
\hline 102 & 95.0 & 600.0 & 325.1 & 5.9 & 3.0 \\
\hline 108 & 70.0 & 550.0 & 325.0 & 5.6 & 3.0 \\
\hline 114 & 35.0 & 450.0 & 325.0 & 5.2 & 3.0 \\
\hline 120 & 25.0 & 300.0 & 325.0 & 5.0 & 3.0 \\
\hline & & & & & \\
\hline
\end{tabular}

Table (3-11): Sartik Dam Inflow, Outflow, and Water levels for 25 years return period flood routing

\begin{tabular}{|c|c|c|c|c|c|}
\hline$T(\mathrm{hr})$ & $\begin{array}{c}\text { Inflow } \\
\left(\mathrm{m}^{3} / \mathrm{s}\right)\end{array}$ & $\begin{array}{c}\text { Outflow } \\
\left(\mathrm{m}^{3} / \mathrm{s}\right)\end{array}$ & $\begin{array}{c}\text { Reservoir } \\
\text { Elevation } \\
\text { (m.a.s.l.) }\end{array}$ & $\begin{array}{c}\text { Head over } \\
\text { weir (H) } \\
(\mathrm{m})\end{array}$ & $\begin{array}{c}\text { Gate } \\
\text { Opening } \\
(\mathrm{Y})(\mathrm{m})\end{array}$ \\
\hline 0 & 90.0 & 50.0 & 325.0 & 5.0 & 2.0 \\
\hline 6 & 105.0 & 50.0 & 325.0 & 5.0 & 2.0 \\
\hline 12 & 190.0 & 70.0 & 325.0 & 5.0 & 2.0 \\
\hline 18 & 470.0 & 100.0 & 325.0 & 5.0 & 2.0 \\
\hline 24 & 1230.0 & 500.0 & 325.1 & 5.1 & 2.0 \\
\hline 30 & 1820.0 & 700.0 & 325.6 & 5.6 & 2.0 \\
\hline 36 & 1990.0 & 900.0 & 326.2 & 6.2 & 2.0 \\
\hline 42 & 1865.0 & 1000.0 & 326.7 & 6.7 & 2.0 \\
\hline 48 & 1590.0 & 950.0 & 327.0 & 7.0 & 2.0 \\
\hline 54 & 1275.0 & 900.0 & 327.3 & 7.3 & 2.0 \\
\hline 60 & 955.0 & 850.0 & 327.4 & 7.4 & 2.0 \\
\hline 66 & 685.0 & 800.0 & 327.3 & 7.3 & 2.0 \\
\hline 72 & 500.0 & 750.0 & 327.2 & 7.2 & 2.0 \\
\hline 78 & 365.0 & 700.0 & 327.1 & 7.1 & 2.0 \\
\hline 84 & 260.0 & 670.0 & 327.0 & 7.0 & 2.0 \\
\hline 90 & 185.0 & 640.0 & 326.7 & 6.7 & 2.0 \\
\hline 96 & 100.0 & 600.0 & 326.4 & 6.4 & 2.0 \\
\hline 102 & 80.0 & 570.0 & 326.2 & 6.2 & 2.0 \\
\hline 108 & 45.0 & 530.0 & 326.0 & 6.0 & 2.0 \\
\hline 114 & 35.0 & 500.0 & 325.7 & 5.7 & 2.0 \\
\hline 120 & 25.0 & 400.0 & 325.1 & 5.1 & 2.0 \\
\hline & & & & & \\
\hline & & & & & \\
\hline
\end{tabular}

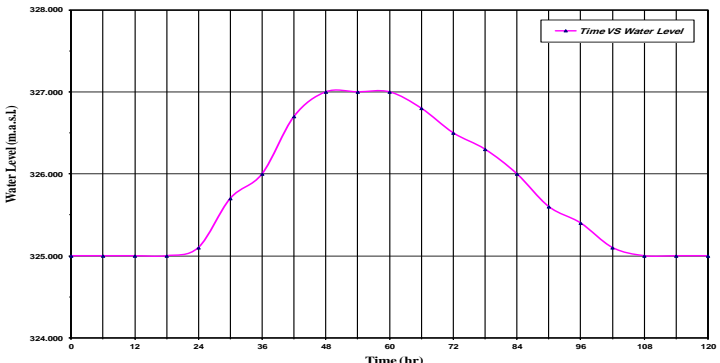

Fig.( 14-a ) : 50 Years Return Period Flood Time \& Water Elevation relation for Sartik Dam Spillway

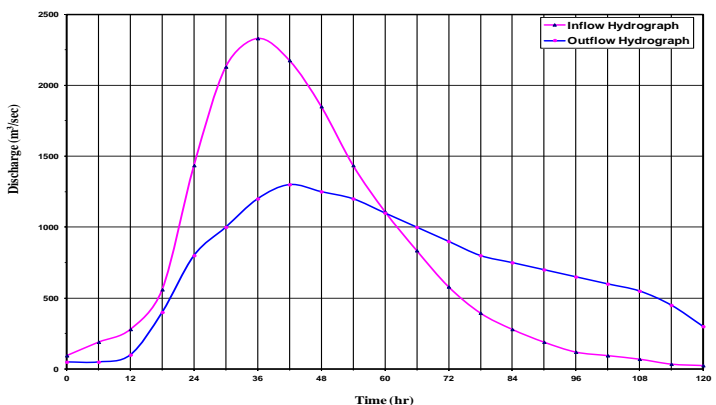

Fig.( 14 - b ) : 50 Years Return Period Flood Inflow \& Outflow Hydrographs for Sartik Dam Spillway

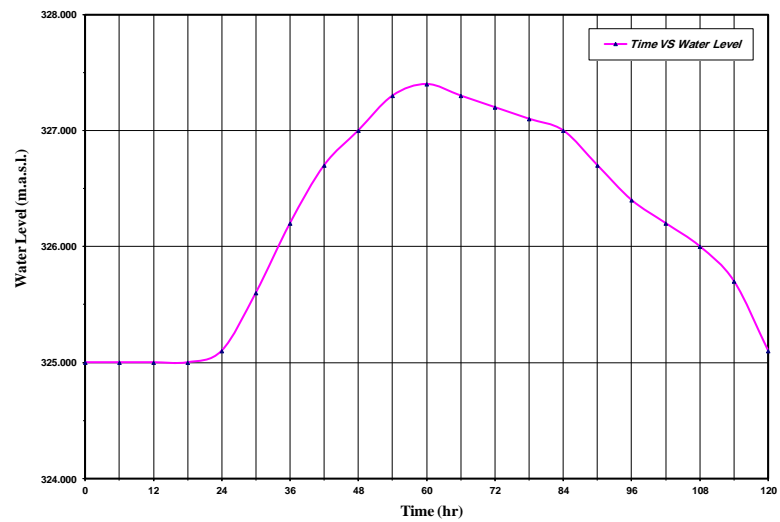

Fig.( 15-a ) : 25 Years Return Period Flood Time \& Water Elevation relation for Sartik Dam Spillway

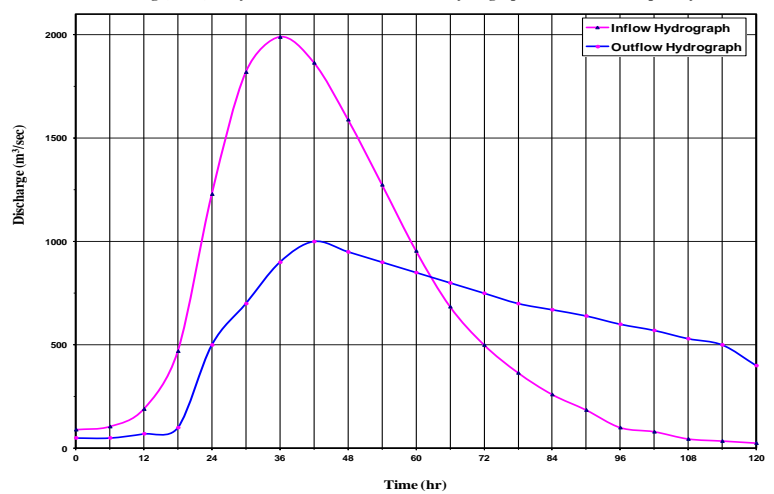

Fig.( 15 - b ) : 25 Years Return Period Flood Inflow \& Outflow Hydrographs for Sartik Dam Spillway 


\section{CONCLUSIONS}

1 - Construction of Sartik Dam aims to increase the firm irrigation discharge up to $125 \mathrm{~m}^{3} / \mathrm{sec}$. The dam may have a power generating facility with an installed capacity amounting to $156 \mathrm{MW}$ with a maximum discharge of $300 \mathrm{~m}^{3} / \mathrm{sec}$.

2- The height of proposed dam reservoir storage is $40 \mathrm{~m}$. The dead storage elevation was provided at 309 m.a.s.l. this level gives dead storage volume equal to $\left(104,304,031 \mathrm{~m}^{3}\right)$, and the normal water level is fixed at 325 m.a.s.l. which gives live storage capacity equal to $(384,846,885)$ and flooded area equal to $\left(34.184 \mathrm{~km}^{2}\right)$.

3- From the simulation model of the Sartik dam reservoir, for different water (dry, average, and wet) years inflow hydrographs, it was clear that the reservoir starts full at month April and ends full at month March during one year taking in account that the maximum water storage in the reservoir is $(489,150,916) \mathrm{m}^{3}$ and minimum storage is $(104,304,031) \mathrm{m}^{3}$

4- Flood routing was conducted to find outflow hydrographs and maximum water level in the dam reservoir for $(25,50,100,1000$ years and PMF) return period's inflow hydrographs. The probable maximum flood (PMF) routing results showed that the maximum outflow from Sartik reservoir was $\left(6456.42 \mathrm{~m}^{3} / \mathrm{sec}\right)$, and the maximum water level reached 330.21 m.a.s.l.

5- According to hydrologic study it is recommended to built the dam because the project will active the agriculture system in the area and solving the draught action in the area by producing different types of summer crops during draught season and producing Electricity, increasing the animal production and fish breeding, also there is indirect benefit of this project by recharging the ground water.

\section{REFERENCES}

1. Al-Furat Co., "Altun Kopri Dam Project, Preliminary selection of structures sites," 2003.

2. Binnie, Deacon and Gourley: "The Dokan Dam Project Report", London 1959.

3. David R. Maiment, "Hand Book of Hydrology" Published by McGRAW-HILL, 1993.

4. D.L. VISHER \& W.H. HAGER, "Dam Hydraulics", Published by by John Willey \& Sons, 1998.

5. Harza, Binnie \& Partners: "Hydrological Survey of Iraq", July 1963.

6. Ishaq, M. B., "Optimum Operation Rules for TigrisEuphrates system in Iraq," Ph. D. Thesis, University of Baghdad, College of Engineering, Iraq, April 1998.

7. ITSC HYDRO ENGINEERING and STUCKYSWITZERLAND "Taq Taq Dam Project Hydrology Report", 2006

8. Mark J. Hammer \& Kenneth A., Hydrology and quality of water resources, published by John Willey \& Sons, 1981.

9. Rasheed, M. M., "Optimum Operation for Saddam and Dokan Reservoirs and their Effects on Tigris River," M. Sc. Thesis, University of Baghdad, College of Engineering, Iraq, December 1998.

10. Richardson, Harvey, unpublished document, Massachusetts Soil Conservation Service, 1969.

11. Soil Conservation Service, Hydrology, Sec. 4 of National Engineering Handbook, U.S. Dept. of Agriculture, Washington, D.C., 1972.

12. Selkhozpromexport: "General Scheme of Water Resources and Land Development in Iraq", Baghdad-Moscow, 1975.

13. SWECO: "Lesser-Zab Regulation Project", Feasibility Report, Stockholm 1982.

14. The General Commission of Meteorology: "Records of Kirkuk, Sulaimani and Dokan stations".

15. The General Commission of Dams and Reservoirs: "Hydrological records of Lesser Zab-River".

16. White W.R.-Milli,"SedimentTransport Theories A review", Proc.Inst.Civ.Eng., part2,1975.

17. Sando P. Nikolov, "Rainfall Erosion in Northern Iraq an Aid to Soil Conservation", Baghdad, 1983.

18. Vector Miguel Ponce, "Engineering Hydrology Principles and Practice" Pub. by McGRAWHILL, 1998. 